\title{
Prescribed defoliation strategies influence soil carbon dynamics and nitrous oxide emission potential in West Virginia pastures
}

Jordan M.A Koos

Follow this and additional works at: https://researchrepository.wvu.edu/etd

\section{Recommended Citation}

Koos, Jordan M.A, "Prescribed defoliation strategies influence soil carbon dynamics and nitrous oxide emission potential in West Virginia pastures" (2018). Graduate Theses, Dissertations, and Problem Reports. 7201.

https://researchrepository.wvu.edu/etd/7201

This Thesis is protected by copyright and/or related rights. It has been brought to you by the The Research Repository @ WVU with permission from the rights-holder(s). You are free to use this Thesis in any way that is permitted by the copyright and related rights legislation that applies to your use. For other uses you must obtain permission from the rights-holder(s) directly, unless additional rights are indicated by a Creative Commons license in the record and/ or on the work itself. This Thesis has been accepted for inclusion in WVU Graduate Theses, Dissertations, and Problem Reports collection by an authorized administrator of The Research Repository @ WVU. For more information, please contact researchrepository@mail.wvu.edu. 
Prescribed defoliation strategies influence soil carbon dynamics and nitrous oxide emission potential in West Virginia pastures

\author{
Jordan M.A. Koos
}

Thesis submitted to the Davis College of Agriculture, Natural Resources and Design at West Virginia University in partial fulfillment of the requirements for the degree of

\title{
Master of Science
}

In

Applied and Environmental Microbiology

\author{
Dr. Zachary Freedman, Ph.D., Chair \\ Dr. Charlene Kelly, Ph.D. \\ Dr. Thomas Griggs, Ph.D.
}

Division of Plant and Soil Sciences
Morgantown, West Virginia
2018

Keywords: (grassland management, nitrous oxide, carbon sequestration, microbial ecology) Copyright 2018 Jordan Koos 


\begin{abstract}
Prescribed defoliation strategies influence soil carbon dynamics and nitrous oxide emission potential in West Virginia pastures
\end{abstract}

Jordan M.A. Koos

Growing interest in sustainable agriculture has driven inquiry into the impacts of grazing on cool-season perennial grasslands, which are commonly utilized as forage for ruminant livestock in West Virginia and throughout the Central Appalachian region. However, current understanding of the below-ground impacts of forage defoliation (i.e., one selective pressure applied by grazing livestock) management strategies is nascent. The aim of this thesis is to investigate how defoliation management strategies affect above-ground (e.g., forage production) and below-ground processes (e.g., soil organic matter (SOM) accumulation, microbial carbon, nitrogen, and phosphorus $(\mathrm{P})$ cycling capacity, and nitrous oxide $\left(\mathrm{N}_{2} \mathrm{O}\right)$ emission potential). I hypothesized that the rotational (i.e., moderate frequency) defoliation at low severity will increase SOM storage and the microbial capacity to cycle C, N, and P. However, I also hypothesize that the greatest $\mathrm{N}_{2} \mathrm{O}$ emission capacity will also come from plots defoliated at a moderate frequency and low severity, due to greater below-ground $\mathrm{C}$ availability that will stimulate microbial activity. To address these hypotheses, data were collected from two West Virginia University Research Farms, one organically managed and one conventionally managed, each with experimental plots where forage defoliation treatments of increasing intensity and frequency have been implemented since May 2016. At the completion of two growing seasons, above- and below-ground parameters of interest were recorded, including leaf area index, forage utilization, stable and recalcitrant $\mathrm{C}$ pools, extracellular enzyme activities associated with microbial $\mathrm{C}, \mathrm{N}$, and $\mathrm{P}$ acquisition, and $\mathrm{N}_{2} \mathrm{O}$ emission potential via quantification of microbial genes by qPCR. At the Organic farm, greater defoliation severity decreased labile carbon content in the soil (-21\%). Further, at the Organic Farm, defoliation treatments at rotational frequency and low severity resulted in a $39 \%$ reduction in $\beta$-glucosidase activity, however $\beta$-glucosidase activity was not impacted by defoliation frequency or severity at the Reedsville Farm. In addition, $\mathrm{N}_{2} \mathrm{O}$ emission potential was differentially affected by defoliation treatments at the two sites. At the Organic Farm, defoliation severity impacted $\mathrm{N}_{2} \mathrm{O}$ emission potential, whereby low defoliation severity resulted in $82 \%$ decrease in potential $\mathrm{N}_{2} \mathrm{O}$ emissions compared to high defoliation severity. At the Reedsville Farm, defoliation frequency impacted $\mathrm{N}_{2} \mathrm{O}$ emission potential, whereby continuously defoliated plots experienced a $71 \%$ decrease in potential $\mathrm{N}_{2} \mathrm{O}$ emissions compared to less frequent defoliation treatments. Taken together, these results suggest that defoliation management is capable of increasing soil $\mathrm{C}$ storage at the cost of increased nitrous oxide emission potential. However, management prescriptions must consider site specific nutrient dynamics to most accurately predict defoliation management impacts on soil $\mathrm{C}$. 


\section{Acknowledgements}

I must thank all the members of the Freedman lab including: Greg Martin, Brianna Mayfield, Jenni Kane, Elisabeth Six, and Nick Dolan. Each of them has aided in my success whether it be through help in the lab, writing, or being there for personal development. I must also thank Angie Macias for aiding me in course work and my growth as a scientist. I thank my committee members Zachary Freedman, Charley Kelly, and Tom Griggs for challenging me in our meetings and helping me develop my ideas. I must give special thanks to my advisor Zachary Freedman for his unwavering commitment and dedication to my education and future successes. Funding for this research was provided by a West Virginia University and West Virginia Natural Resource Conservation Service (NRCS) cooperative. 


\section{Table of Contents}

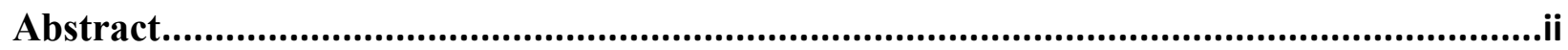

Acknowledgements................................................................................................................ii

Table of Contents .............................................................................................................

Chapter 1: Defoliation management alters soil microbial enzyme activities in West Virginia

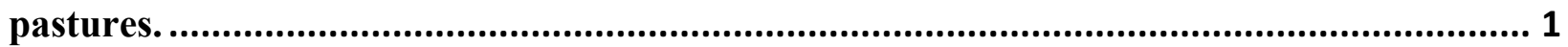

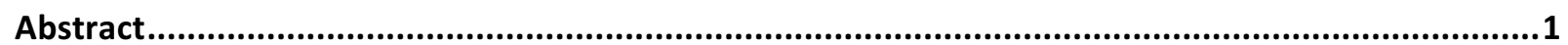

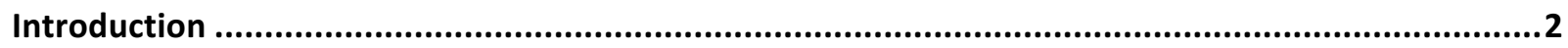

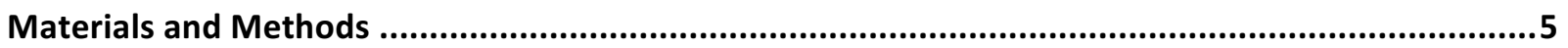

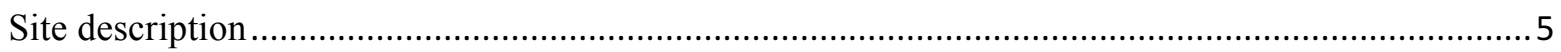

Assessments of Forage Photosynthetic Capacity and Predicted Utilization by Grazing Livestock...... 7

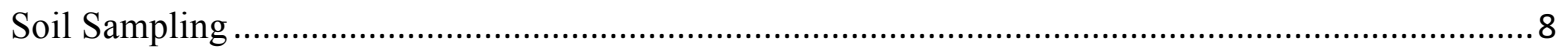

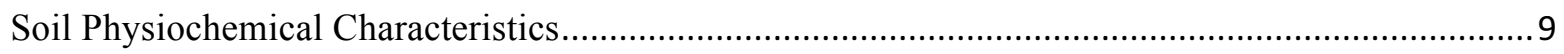

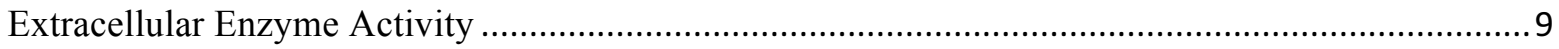

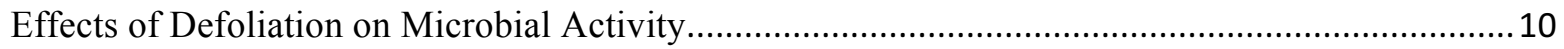

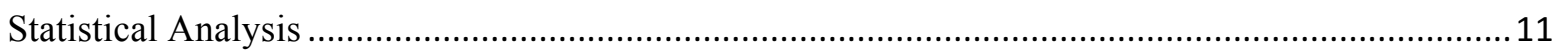

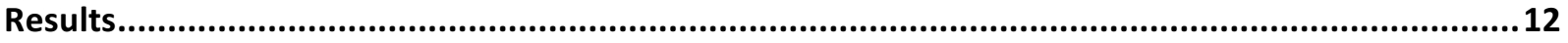

Differences between sites following defoliation implementation ............................................... 12

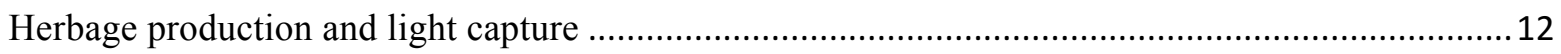

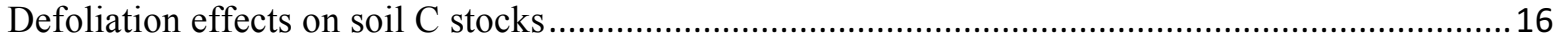

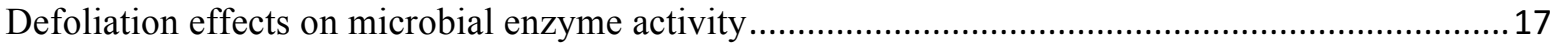

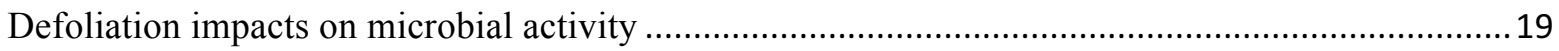

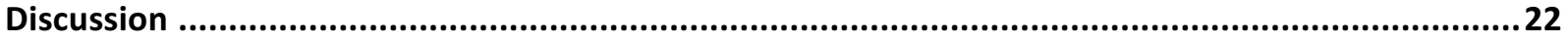

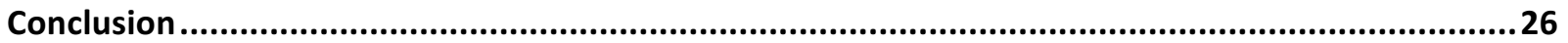

Chapter 2: Greater soil carbon increases nitrous oxide emission potential in two West

Virginia pastures.............................................................................................................28

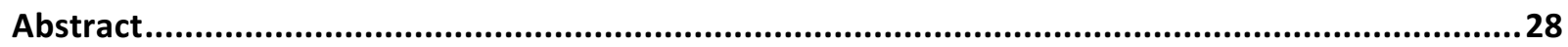

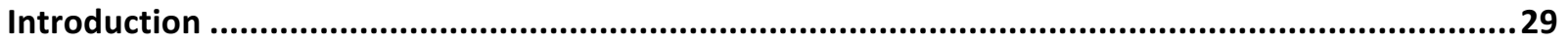

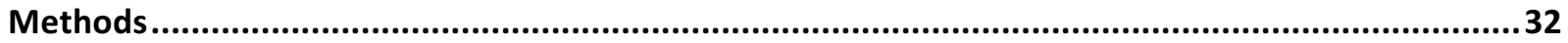

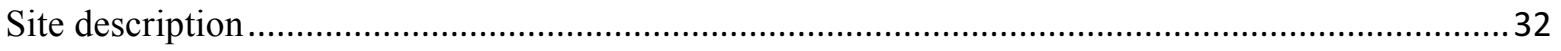

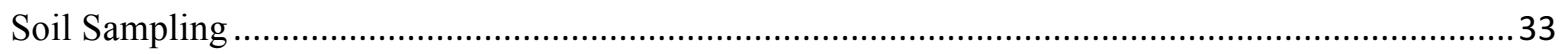

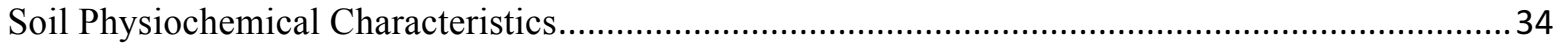

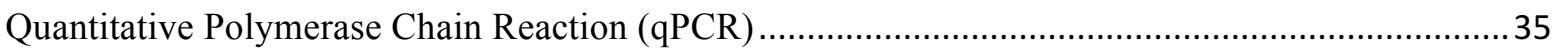

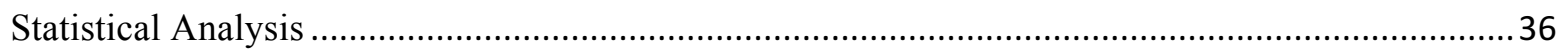

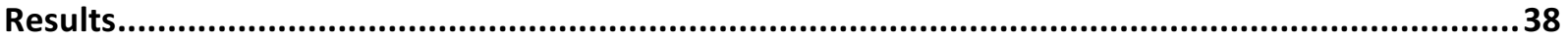

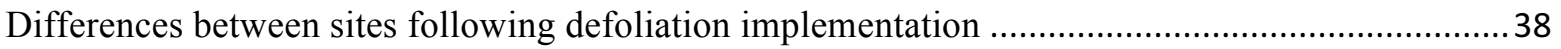

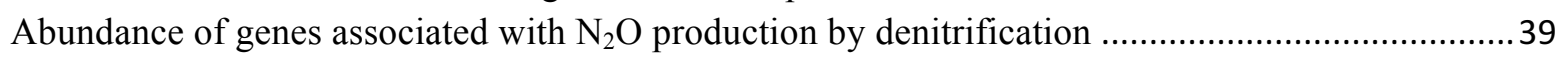

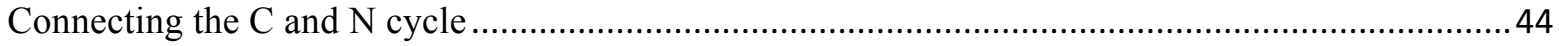

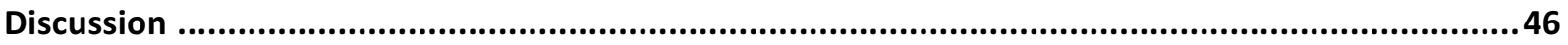

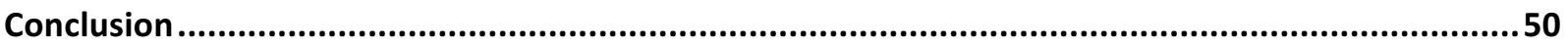

Works Cited ..........................................................................................................................51 
Chapter 1: Defoliation management alters soil microbial enzyme activities in West Virginia pastures.

\begin{abstract}
Growing interest in sustainable agriculture has driven research into the impacts of grazing on cool-season perennial grasslands, which are commonly utilized as forage for ruminant livestock in West Virginia and throughout Central Appalachia. Soil carbon (C) dynamics and microbial activity are commonly utilized indicators of soil health, but how defoliation management may affect these parameters in Appalachia is still unknown. The aim of this study is to investigate how defoliation management strategies affect above-ground parameters (e.g., forage utilization and leaf-area index) as well as below-ground parameters such as soil $\mathrm{C}$ pools and soil microbial enzyme activities associated with $\mathrm{C}$, nitrogen $(\mathrm{N})$, and phosphorus $(\mathrm{P})$ acquisition. Examination of defoliation impacts on soil $\mathrm{C}$ pools and microbial enzyme activities is important for predicting the environmental sustainability of defoliation management in these systems. I hypothesize that moderate (i.e., monthly) defoliation events at low severity will produce greater herbage utilization and light-capture efficiency, which will result in increased accumulation of labile $\mathrm{C}$ below-ground. I further hypothesize that such increases in soil $\mathrm{C}$ storage will reduce microbial nutrient demands for $\mathrm{C}$ and increase enzyme production associated with $\mathrm{N}$ and $\mathrm{P}$ acquisition. To address these hypotheses, I implemented experimental defoliation treatments at two West Virginia University Research Farms of increasing intensity and frequency, beginning in July 2016. After two full growing seasons, I collected data for several below- and above-ground parameters of interest such as, leaf area index, utilization, labile and recalcitrant soil $\mathrm{C}$ pools, as well as microbial extracellular enzyme activities associated with $\mathrm{C}$, $\mathrm{N}$, and $\mathrm{P}$ acquisition. Defoliation management resulted in decreased utilization and light capture in continuously defoliated treatments. In addition, enzyme activities related to microbial $\mathrm{N}$ and $\mathrm{P}$ acquisition were unaffected by the defoliation treatments, however $\beta$-glucosidase activity was affected by defoliation management. Variation in microbial activities were largely dependent on soil moisture and parameters associated with $\mathrm{C}$. These data will develop our understanding of the below-ground impacts of grazing and inform more effective management plans for livestock grazing of perennial pastures in West Virginia and the Central Appalachian region.
\end{abstract}




\section{Introduction}

Sustainable management of agricultural lands is essential for the maintenance of soil quality and provides environmental and economic benefits for both society and growers. The accumulation of carbon (C) as soil organic matter (SOM) is a commonly used indicator of soil quality and it is also important for mitigating elevated atmospheric $\mathrm{CO}_{2}$ and anthropogenic climate change $(1,2)$. Greater SOM increases yields, cation exchange capacity, water availability, water holding capacity and process rates of critical ecosystem functions (i.e., soil fertility (3-5). Through mineralization by decomposition, the organic $\mathrm{C}$ fraction of soil is the main source of $\mathrm{C}$ available to soil organisms (6), and the mean residence time (MRT) of soil organic C (SOC) is determined by physical, chemical, microbial, and ecological dynamics $(7,8)$. In Appalachia, a dominant land use type is pasture for livestock grazing, and in West Virginia, pasture represents the greatest single agricultural land use type in the state $(11 \%$ of land in WV is currently in pasture; (9)), thus, proper management of pasture lands can have impacts on the cycling and storage of SOC, and ultimately, soil fertility across this region. The top-down ecological, physical, and chemical effects of livestock grazing on above-ground processes have been studied extensively (10-15); however, the current understanding of grazing impacts on belowground dynamics is nascent (16-23). By isolating pasture defoliation, which is a selective pressure applied by grazing livestock, this study aims to increase understanding of defoliation impacts on soil $\mathrm{C}$ dynamics and the soil microbial community's ability to cycle critical soil nutrients (e.g., C, nitrogen $(\mathrm{N})$, and phosphorous (P)). Findings from this project will help guide agricultural land management strategies to increase stable soil organic $\mathrm{C}$, which will increase soil 
fertility and environmental sustainability of this environmentally and economically important land-use type.

Soil quality in pasture lands can by impacted by defoliation frequency and severity through defoliation-induced shifts in plant species composition, which can alter litterfall quality and quantity, plant rooting structures, and soil microenvironments $(13,14)$. For example, increasing defoliation frequency shifted the composition of grasses to shorter more defoliationtolerant grasses, which have apical meristems closer to the ground that provides an ability to regrow - thus providing an advantage under severe defoliation (24). Further, increases in defoliation frequency and severity can shift pastures from $\mathrm{C}_{3}$ grasses (e.g., Stipa) to $\mathrm{C}_{4}$ grasses (e.g., Bouteloua), which are less suitable feedstock and whose biochemical composition may decrease decomposition rates compared to $\mathrm{C}_{3}$ grasses $(25,26)$. Further, in a Chinese steppe under increased grazing frequency and severity, the dominant plant type in the community changed (e.g., from grasses to sedges or forbs) which can lead to a more pronounced change in feedstock suitability (27). Thus, grazing impacts on plant community composition and diversity can directly impact the decomposability of plant materials and SOC dynamics $(28,29)$. The direction and magnitude of changes to SOC pools and nutrient turnover rates may depend on the original and new pasture grass types, as well as the frequency and/or severity of defoliation.

Defoliation-induced changes in plant community composition can occur simultaneously with changes in plant physiology, which is one potential factor linking above- and belowground dynamics that mediate soil $\mathrm{C}$ storage. A plausible mechanism driving changes in plant physiology under increased defoliation frequency and severity is the differential physiological responses of forage species $(14,30)$. For example, compensatory regrowth (i.e., the accelerated growth of plant biomass following defoliation events) is an important process regulating the 
productivity and biochemistry of foraged tissues $(12,31)$. Following defoliation, new leaf tissue may have lower C:N (32) and increased decomposability as compared to older leaf tissue (30, 33, 34). Belowground, plant residues, root turnover, and root exudates are all significant $\mathrm{C}$ inputs to SOC, which promote microbial growth, necromass, and metabolism $(8,35)$. Impacts of defoliation on root turnover are highly variable, as roots have been shown to increase or decrease in mass, as well as stop growth entirely under various defoliation management strategies $(22,23$, 27, 36). Most importantly, plants roots are responsible for exuding low molecular weight (LMW) compounds, which provide the microbial community with labile sources of $\mathrm{C}$ that can increase microbial activity and growth $(37,38)$. Foliar defoliation has been shown to increase plant root exudation, subsequently increasing microbial abundance, and ultimately microbial necromass, which supports the accumulation of stable SOC (39). Thus, the timing and severity of pasture defoliation can have cascading impacts on rooting dynamics and soil microbial substrate availability, which can then feedback to affect long-term soil C storage.

Decomposition, which is a microbially-mediated process, is critical to the cycling and storage of nutrients in soil (40-43). For example, decomposition products make up the majority of stable $\operatorname{SOM}(6,43-45)$. Microbes mediate decomposition through a suite of extracellular enzymes, which can serve as biological indicators of soil health and microbial nutrient demands $(41,46)$. These enzymes contribute to the breakdown of polyphenolic organic compounds such as lignin, cellulose, and hemicellulose, as well as to the acquisition of $\mathrm{N}$ and P from $\operatorname{SOM}(1,2$, 47). The activity of microbial exoenzymes can be affected by changes in environmental conditions. For example, in pasture lands, microbial enzyme activities associated with decomposition increased after introducing sheep, and further, rates of decomposition were greater under light defoliation compared to heavy defoliation by sheep (48). These results 
demonstrate the need to identify and develop best management practices (BMPs) for pasture grazing that promote healthy soil microbial communities and optimal rates of decomposition, potentially increasing the $\mathrm{C}$ storage capacity of pasture soils.

Here, I investigate whether a top-down ecological cascade commencing with the defoliation of forage plants alters the availability of labile and recalcitrant $\mathrm{C}$ pools for microbial use, and further, whether differences in defoliation management strategy (i.e. frequency and severity) alter microbial enzyme activities and nutrient foraging $(8,49)$. My objective is to inform the development of best management practices for pasture managers by determining a treatment that increases SOC while maximizing forage production. I hypothesize that moderate (i.e., monthly) defoliation events at a low severity (i.e., $13 \mathrm{~cm}$ height) will produce greater herbage mass and productivity than continuous or hay defoliation frequencies resulting in increased below-ground C storage. I further hypothesize that the increases in soil C storage will reduce microbial extracellular enzyme production associated with $\mathrm{C}$ acquisition and increase enzyme production associated with $\mathrm{N}$ and $\mathrm{P}$ acquisition. To test these hypotheses, six defoliation treatments were implemented at an organically managed farm and a conventionally managed farm in West Virginia to examine how differences in defoliation frequency and severity affect SOC formation and microbial $\mathrm{C}, \mathrm{N}$, and $\mathrm{P}$ cycling potential.

\section{$\underline{\text { Site description }}$}

\section{Materials and Methods}

This experiment was conducted at two West Virginia University (WVU) research farms: The Organic Agriculture Farm in Morgantown, WV (395N, -79 $94 \mathrm{~W}$; hereafter "OF") and the JW Ruby Research Farm in Reedsville, WV (39 1 N, -79 $82 \mathrm{~W}$; hereafter "RV"; Table 1). The OF was organically certified in 1998 , and the RV site is conventionally managed. Soils at OF 
and RV consist of Dormont silt loam (Fine-loamy, mixed, superactive, mesic Oxyaquic Hapludalfs) and Latham silt loam (Fine, mixed, semiactive, mesic Aquic Hapludults), respectively. Mean annual temperature (MAT) and mean annual precipitation (MAP) are $20.3^{\circ} \mathrm{C}$ and $125.5 \mathrm{~cm}$, respectively, at $\mathrm{OF}$ and $12^{\circ} \mathrm{C}$ and $153 \mathrm{~cm}$ at $\mathrm{RV}$. Experimental plots were established at each site in June 2016, plots measured $7 \mathrm{~m} \times 3 \mathrm{~m}$ at OF and $8 \mathrm{~m} \times 3 \mathrm{~m}$ at RV. On July 1, 2016, six experimental defoliation treatments consisting of three simulated frequency regimes at two levels of severity were implemented at each site (Table 2) in a randomized block design ( 3 frequency levels $\times 2$ severity levels $\times 3$ blocks $\times 2$ sites $=36$ total plots). The simulated grazing by defoliation frequency and severity treatments were selected to align with common pasture management strategies in the Central Appalachian region, representing continuous, rotational, and hay-stage pasture management as suggested by the United States Department of Agriculture Natural Resources Conservation Service (50). The continuous frequency treatment was defoliated every 7-10 days, rotational frequency plots were defoliated every 28-35 days, and hay-stage plots were defoliated every 42-45 days. Each simulated frequency treatment was also defoliated to two heights to represent low and high severity defoliation, respectively; the defoliation height was $6-8 \mathrm{~cm}$ for the high severity treatment and $13 \mathrm{~cm}$ for the low severity treatment. Simulated defoliation was achieved by clipping vegetation using a Monarch SickleBar Mower outfit with a 36-inch serrated sickle bar (Jari USA, St. Peter, Minnesota). 
Table 1: Summary characteristics of each experimental site in West Virginia.

$$
\text { Organic Farm Reedsville }
$$

\begin{tabular}{lcc}
\hline Coordinates & $39^{\circ} 5 \mathrm{~N},-79^{\circ} 94 \mathrm{~W}$ & $39^{\circ} 1 \mathrm{~N},-79^{\circ} 82 \mathrm{~W}$ \\
Soil Series & Dormont Silt Loam & Latham Silt Loam \\
Management & Organic & Conventional \\
MAP (51) & $125.5 \mathrm{~cm}$ & $153.0 \mathrm{~cm}$ \\
MAT(51) & $20.3^{\circ} \mathrm{C}$ & $12^{\circ} \mathrm{C}$ \\
Relative N/P/K & High/Low $/ \mathrm{High}$ & High/High/Low \\
\hline
\end{tabular}

Table 2: The six experimental treatments included in this experiment identified by defoliation frequency and severity (clipped stubble height).

\begin{tabular}{lcccccc}
\hline & A & B & C & D & E & F \\
\hline Frequency & Rotational & Rotational & Continuous & Continuous & Hay & Hay \\
Severity & $6 \mathrm{~cm}$ & $13 \mathrm{~cm}$ & $8 \mathrm{~cm}$ & $13 \mathrm{~cm}$ & $6 \mathrm{~cm}$ & $13 \mathrm{~cm}$ \\
\hline
\end{tabular}

Assessments of forage photosynthetic capacity and predicted utilization by grazing livestock

To determine differences in light capture due to defoliation treatment, an ACCUPAR LP80 Ceptometer (Decagon Devices Inc. Pullman, WA) equipped with an external photosynthetically active radiation (PAR) sensor was used to measure light interception and estimate leaf area index (LAI), which is a dimensionless measure of plant canopy area per unit 
ground area. LAI was collected from three different locations within a plot, with three replicate subsamples per location $(n=9)$. When possible, LAI measurements were taken within one hour of solar noon.

I calculated "utilization" as the difference in pre-treatment and post-treatment dry mass of forage. Before and after each clipping event, the masses of forage was recorded, and the difference between before-and-after clip height represents the mass of forage available for grazing ruminants (hereafter referred to as "utilization"). To estimate forage utilization, a meter stick was used to measure the canopy height at ten random locations within a plot before and after clipping. The difference between the before and after canopy heights was then multiplied by 132 to determine estimated herbage utilization $(\mathrm{kg} \mathrm{DM \bullet ha-1}$; sensu (52)).

\section{Soil Sampling}

Soil samples were collected following two seasons of defoliation treatments on November 7, 2017. Plots were randomly sampled 10 times using a soil probe $(1.7 \mathrm{~cm}$ diameter $)$ to a depth of $7.5 \mathrm{~cm}$. The cores were then thoroughly homogenized by hand to produce one composite sample per plot. The homogenized soil samples were stored on ice in the field and returned to the lab within two hours of sampling. Upon return to the lab, each soil sample was

sieved $(2,000 \mu \mathrm{m})$ to remove coarse roots and rocks. Homogenized sieved soil was stored at $4^{\circ} \mathrm{C}$ for enzyme and physicochemical analysis. 


\section{$\underline{\text { Soil Physiochemical Characteristics }}$}

To determine the impact of defoliation on soil properties, soil physiochemical characteristics were assayed that have been shown to impact plant and microbial function. These are $\mathrm{pH}$, soil moisture, total $\mathrm{C}$, total $\mathrm{N}$, soil organic matter content, and permanganate oxidizable C content (i.e., labile C; $(2,32,42,53)$. Soil pH was measured using an Accumet AE 150 probe (Fisher Scientific, Hampton, $\mathrm{NH}$ ) in a 1:5 soil to $0.01 \mathrm{M} \mathrm{CaCl}_{2}$ slurry (54). The moisture content of soil samples was determined gravimetrically, whereby $10 \mathrm{~g}$ of field-moist soil was dried at $105^{\circ} \mathrm{C}$ for 24 hours. Following drying, samples were re-weighted to determine dry mass and then combusted at $505^{\circ} \mathrm{C}$ for 6 hours to determine percent soil organic matter (SOM) content by loss on ignition (LOI). The amount of labile $\mathrm{C}$ was estimated by the permanganate oxidizable $\mathrm{C}$ method (55), whereby four analytical replicates of each sample were assayed using clear 96-well plates (Corning, Corning, NY) on a Synergy HTX plate reader (Biotek, Winooski, VT).

Absorbance was recorded at $550 \mathrm{~nm}$. The total $\mathrm{C}$ and $\mathrm{N}$ content of the soil was determined by combustion analysis in a Carlo Erba 1500 NCS (Carlo Erba, St. Joseph, MI) using 12 mg of dry ground soil.

\section{Extracellular Enzyme Activity}

To determine the impact of prescribed defoliation (the management of harvest) on the microbial capacity to mineralize $\mathrm{C}, \mathrm{N}$, and P from SOM, I assessed the activity of microbiallyderived extracellular enzymes that are associated with the cycling and storage of $\mathrm{C}, \mathrm{N}$, and $\mathrm{P}$ in soil, namely, $\beta$-glucosidase (BG), $\beta$-N-acetylglucosaminidase (NAG), and acid phosphatase (AP, Table 3). Acid phosphatase is an enzyme that hydrolyzes nucleic acids and phospholipids making them biologically available (56). NAG binds to chitin and breaks down chitin into N- 
acetylglucosamine increasing the availability of organic $\mathrm{N}$, which is important for microbial $\mathrm{N}$ acquisition $(2,56)$. Enzyme assays were completed within 48 hours of sampling with previously established methods (57) on a Synergy HTX plate reader (Biotek, Winooski, VT). Enzyme activity assays were performed on opaque plates (Corning, Corning, NY) and read using $365 \mathrm{~nm}$ excitation and $450 \mathrm{~nm}$ emission. Eight analytical replicates were used per soil sample for all assays.

Table 3: Soil microbial enzymes assayed for potential activity. (EC, Enzyme commission classification; MUB, methylumbelliferyl)

\begin{tabular}{|c|c|c|c|c|}
\hline Enzyme & $\begin{array}{l}\text { Common } \\
\text { Abbreviation }\end{array}$ & $\mathrm{EC}$ & $\begin{array}{l}\text { Experimental } \\
\text { Substrate }\end{array}$ & $\begin{array}{l}\text { Environmental } \\
\text { Substrate }\end{array}$ \\
\hline$\beta$-glucosidase & BG & $\begin{array}{l}\mathrm{EC} \\
3.2 .1 .21\end{array}$ & $\begin{array}{l}\text { 4-MUB- } \beta-D- \\
\text { glucoside }\end{array}$ & Cellulose \\
\hline $\begin{array}{l}\beta-N- \\
\text { acetylglucosaminidase }\end{array}$ & NAG & $\begin{array}{l}\mathrm{EC} \\
3.2 .1 .14\end{array}$ & $\begin{array}{l}\text { 4-MUB- } N \text { - } \\
\text { acetyl- } \beta \text {-D- } \\
\text { glucosaminide }\end{array}$ & Chitin \\
\hline Acid Phosphatase & $\mathrm{AP}$ & EC 3.1.3.1 & $\begin{array}{l}\text { 4-MUB- } \\
\text { phosphate }\end{array}$ & $\begin{array}{l}\text { Phosphomonoesters/ } \\
\text { phosphodiesters }\end{array}$ \\
\hline
\end{tabular}

\section{Effects of Defoliation on Microbial Activity}

To determine whether defoliation treatments altered the enzymatic capacity of the microbial community to acquire $\mathrm{C}, \mathrm{N}$, and $\mathrm{P}$, we considered "microbial activity" as the normalized profile of C-, N-, and P-acquiring enzymes (58). Here, enzyme activities were combined in to a single matrix and normalized using the "standardise" function for C-, N- and Pacquiring enzyme activities to contribute equal weight in down-stream analyses using Primer (version 6, Primer-E Ltd., Plymouth, UK). 


\section{$\underline{\text { Statistical Analysis }}$}

Univariate statistical analysis was conducted using the general linear model function in SAS JMP (Version 13, SAS Institute Inc., Cary, NC). A two-way analysis of variance (ANOVA) was performed on each parameter and tested for two main effects (frequency and severity) and their interaction (frequency $\times$ severity). For all statistical tests, results were considered significant at $\alpha<0.05$ and marginally significant at $\alpha<0.10$. If a significant interaction was detected a Student's T-test was used to determine differences among means.

To test the hypothesis that defoliation treatments impact microbial activity (as defined above), a Bray-Curtis dissimilarity matrix was used in a two-way permutational multivariate analysis of variance (PerMANOVA; 58) with defoliation frequency and severity as factors for both study sites. Further, the impact of soil parameters (i.e., soil pH, moisture, C:N, SOM, OXC) on microbial activity was assessed by Distance-based Linear Models (DistLM), wherein the adjusted $\mathrm{r}^{2}$ criterion was used in the "best" model selection (60). Prior to running the best model selection procedure, a marginal DistLM was performed to determine which environmental parameters, when considered individually, accounted for a significant proportion of the variance in microbial activity. Only significant parameters were included in best model selection. To visualize the impacts of defoliation treatments on microbial activity, NMDS ordinations were generated using the vegan package (61) in R (62). Environmental vectors were included as vector overlays of significant environmental parameters from marginal DistLM tests when a defoliation effect was detected. 


\section{Results}

Differences between sites following defoliation implementation

The OF and RV farms were chosen as sites for this experiment due to their unique soil physico-chemical properties and management practices (i.e., organic vs. conventional). For example, average oxidizable $\mathrm{C}$, soil organic matter content, soil $\mathrm{C}: \mathrm{N}$, acid phosphatase activity, NAG activity, $\mathrm{pH}$, and \% soil moisture were all significantly different between the two sites (Table 4). Soils at RV exhibited greater C:N, soil organic matter and oxidizable C content, as well as reduced activities of microbial enzyme as compared to soils at OF.

Table 4: Soil and microbial enzyme parameters at each site. (a) and (b) represent differences between the two sites at $p<0.05$.

\begin{tabular}{|c|c|c|c|}
\hline Parameter & $\overline{\mathrm{OF}}$ & $\mathrm{RV}$ & $\mathrm{SE}$ \\
\hline Soil moisture (\%) & 29.3 & 29.0 & 0.4 \\
\hline $\mathrm{pH}$ & $6.0(a)$ & $6.4(\mathrm{~b})$ & 0.06 \\
\hline Total C & 2.5 & 3.3 & .09 \\
\hline Total N & 0.27 & 0.34 & .007 \\
\hline Soil C:N & $8.83(\mathrm{a})$ & $9.9(b)$ & 0.2 \\
\hline $\operatorname{SOM}(\%)$ & $8.00(\mathrm{a})$ & $9.8(b)$ & 0.1 \\
\hline Oxidizable C $\left(\mathrm{mg} \bullet \mathrm{kg}^{-1}\right)$ & 782.9(a) & $1175.5(b)$ & 48.5 \\
\hline$\beta$-glucosidase $\left(\mu \mathrm{M} \cdot \mathrm{h}^{-1} \cdot \mathrm{g}^{-1}\right)$ & $23.5(\mathrm{a})$ & $16.7(\mathrm{~b})$ & 1.2 \\
\hline $\begin{array}{l}\beta-\mathrm{N}- \\
\text { acetylglucosaminidase }\end{array}$ & $17.2(\mathrm{a})$ & $7.3(b)$ & 1.3 \\
\hline Acid phosphatase & $23.5(\mathrm{a})$ & $49.7(b)$ & 2.8 \\
\hline
\end{tabular}

$\underline{\text { Herbage production and light capture }}$

To determine the effect of defoliation on canopy development and light capture, LAI was measured prior to each defoliation event. Effects of defoliation frequency and severity on LAI 
were significant at both OF and RV, however each site responded differently. At OF LAI was highest in the plots that were defoliated at a lower frequency (Figure 1, ANOVA frequency effect; $p=0.06$ ). At $R V$, there was a moderately significant frequency $\times$ severity interaction (Figure 2, $\mathrm{p}=0.09$ ). Post-hoc tests indicate that at RV, LAI was greater under less severe defoliation (29\% greater than high severity). In addition, LAI was greatest in the hay stocking frequency and lowest in the continuous stocking treatment.

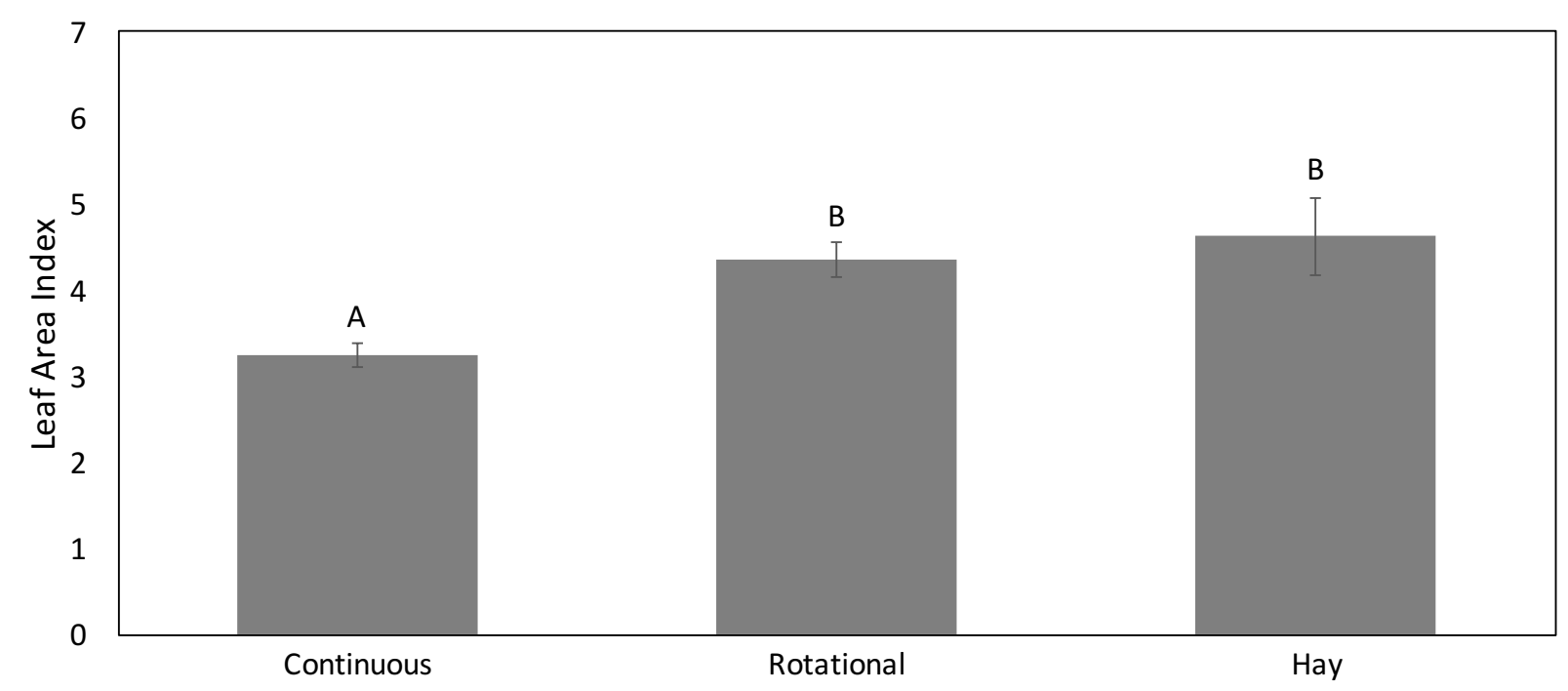

Figure 1: Leaf area index at Organic Farm through the second season of pasture defoliation treatments. LAI was moderately significantly impacted by grazing frequency $(p=0.06)$. Bars represent means $\pm 1 \mathrm{SE}(\mathrm{n}=6)$. Letters indicate significant differences between treatment means. The severity effect was not significant, thus only frequency treatments were included in the figure. 


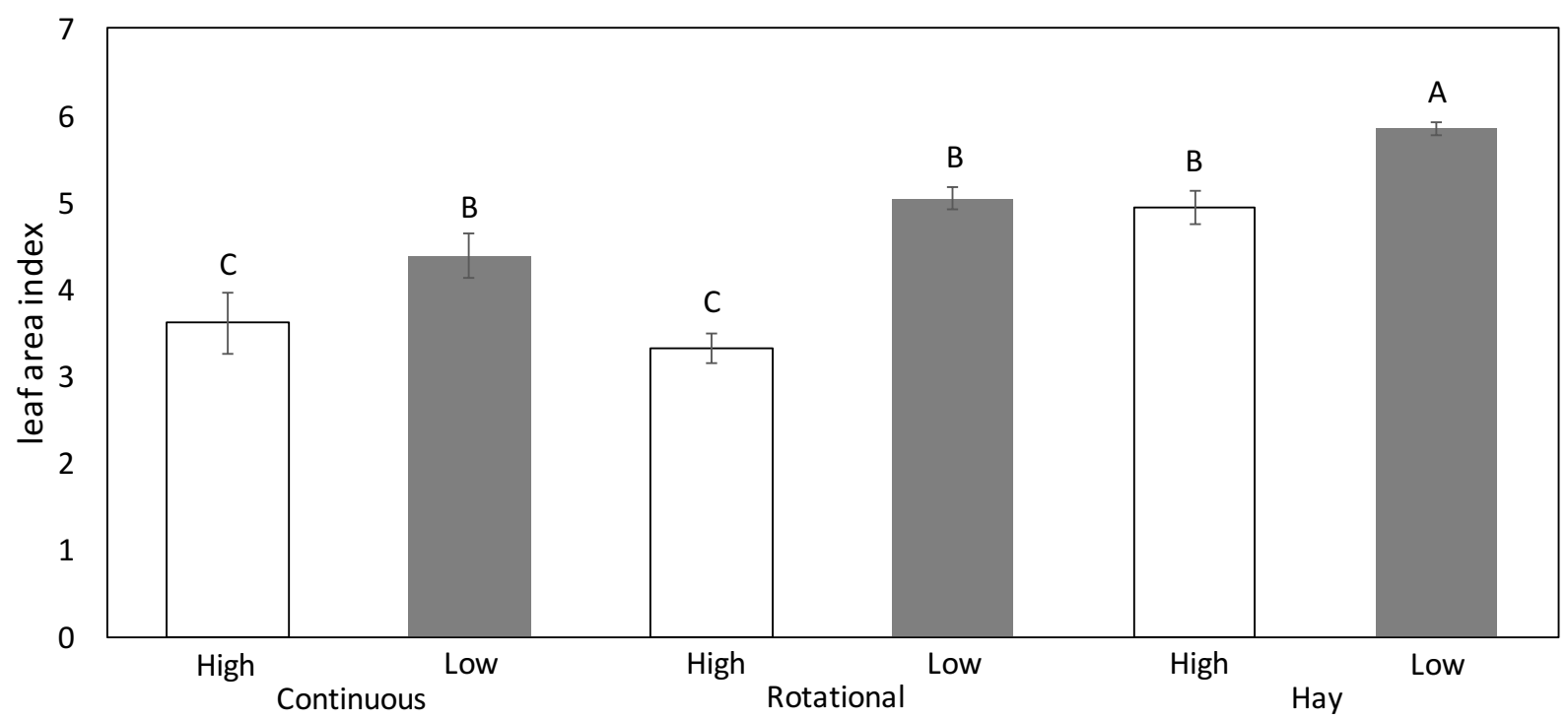

Figure 2: Leaf area index at the Reedsville farm through the second season of pasture defoliation treatments. A significant frequency $\times$ severity interaction was detected. Hollow bars represent high severity clipping. Solid bars represent low severity clipping. Bars are means $\pm 1 \mathrm{SE}(\mathrm{n}=3)$. Letters separate means.

To determine the impact of defoliation frequency and severity on potential forage utilization by livestock, I calculated utilization as described above. At OF, defoliation frequency significantly influenced forage utilization (Figure 3, $\mathrm{p}=0.01$ ), wherein utilization was 30\% lower in rotational stocking plots compared to continuous or hay stocking plots. At RV, both a significant frequency $(\mathrm{p}<0.01)$ and severity $(\mathrm{p}=0.04)$ effect were detected; the interaction term was not significant (Figure 4). Here, low defoliation severity resulted in reduced utilization ($13 \%$ lower than high-severity). Low defoliation frequency also increased utilization, as hay resulted in the highest utilization $\left(9,241 \mathrm{~kg} \mathrm{Dm} \mathrm{ha}^{-1}\right)$ while continuous resulted in the lowest utilization $\left(6,348 \mathrm{~kg} \mathrm{Dm} \mathrm{ha}{ }^{-1}\right)$. 


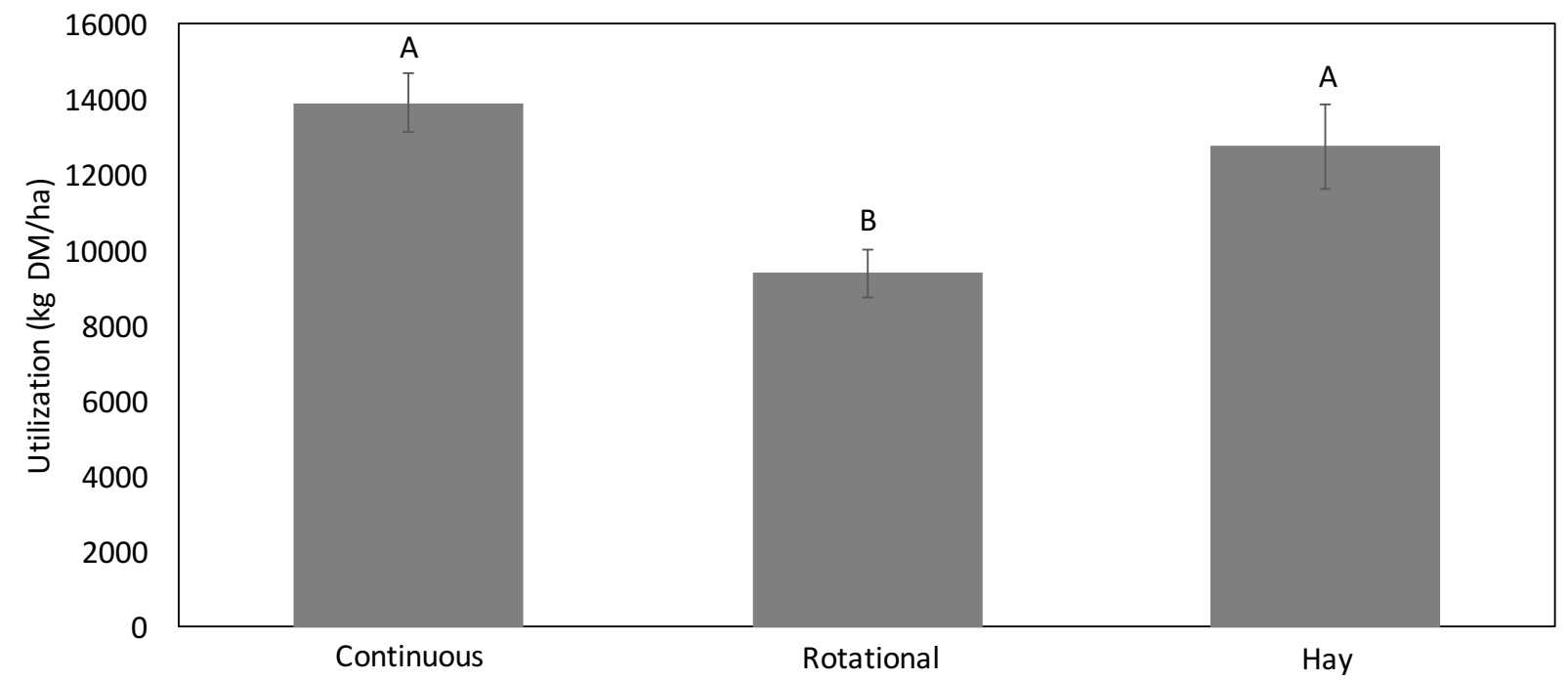

Figure 3: Utilization at OF through the second season of pasture defoliation treatments. Utilization was different across defoliation frequencies $(\mathrm{p}=0.01)$ No significant defoliation severity effect nor a frequency $\times$ severity interaction was detected. Bars represent means $\pm 1 \mathrm{SE}$ $(n=6)$.

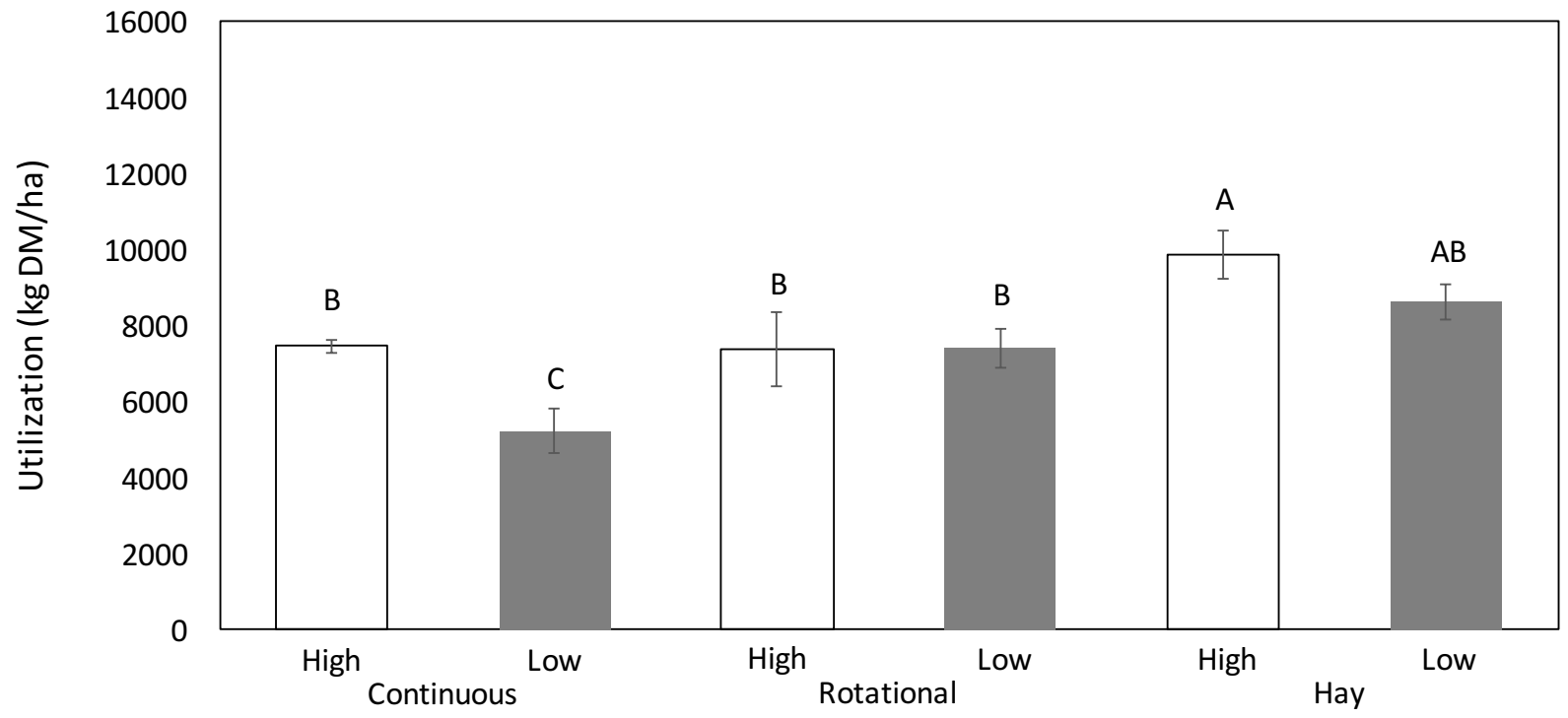

Figure 4: Utilization at RV through the second season of pasture defoliation treatments.

Defoliation frequency and severity treatments were significantly different. Bars represent means $\pm 1 \mathrm{SE}(\mathrm{n}=3)$. Letters separate means. 


\section{$\underline{\text { Defoliation effects on soil C stocks }}$}

To test for differences in soil C stocks due to defoliation frequency and severity, total C, total $\mathrm{N}$, SOM, as well as permanganate oxidizable $\mathrm{C}$ (OXC; i.e., labile $\mathrm{C})$ were measured. At both $\mathrm{OF}$ and $\mathrm{RV}$, total $\mathrm{C}$, total $\mathrm{N}, \mathrm{C}: \mathrm{N}$ and \% SOM were not significantly different due to any defoliation effect or interaction. However, at OF, OXC was significantly influenced by defoliation severity, as OXC activity was 25,45 , and $47 \%$ greater in high defoliation severity plots compared to low severity plots under continuous, rotational, and hay stocking rates, respectively. Overall at $\mathrm{OF}, \mathrm{OXC}$ was $30 \%$ greater in low severity plots as compared to high severity plots (Figure 5 , severity effect $\mathrm{p}=0.06$ ). At $\mathrm{RV}$, there was no impact of defoliation frequency or severity on OXC (Figure 6).

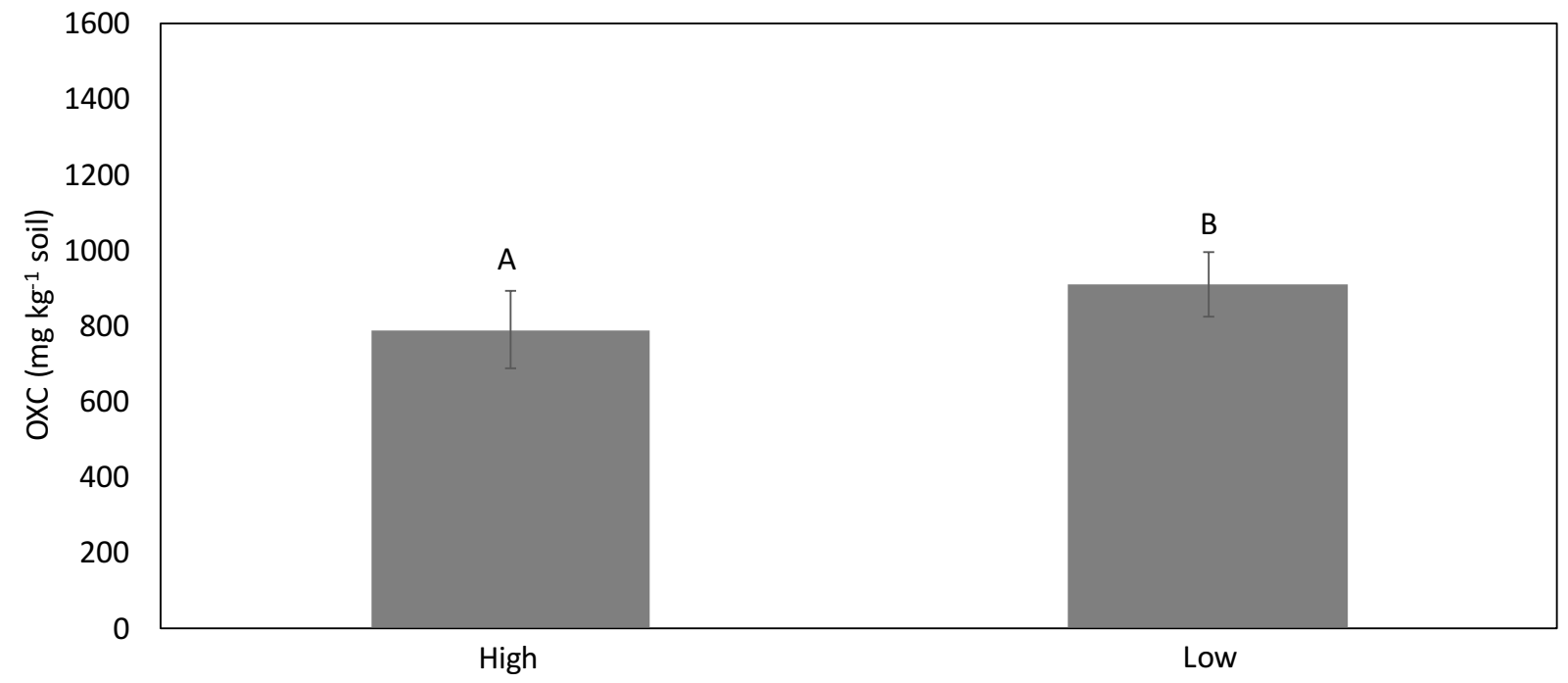

Figure 5: Oxidizable carbon (OXC), 0-7.62 cm depth at $\mathrm{OF}$ following two seasons of defoliation treatment. No significant defoliation frequency effect nor a frequency $\times$ severity interaction was exhibited. Severity effect $\mathrm{P}<0.05$. Bars represent means $\pm 1 \mathrm{SE}(\mathrm{n}=3)$. 


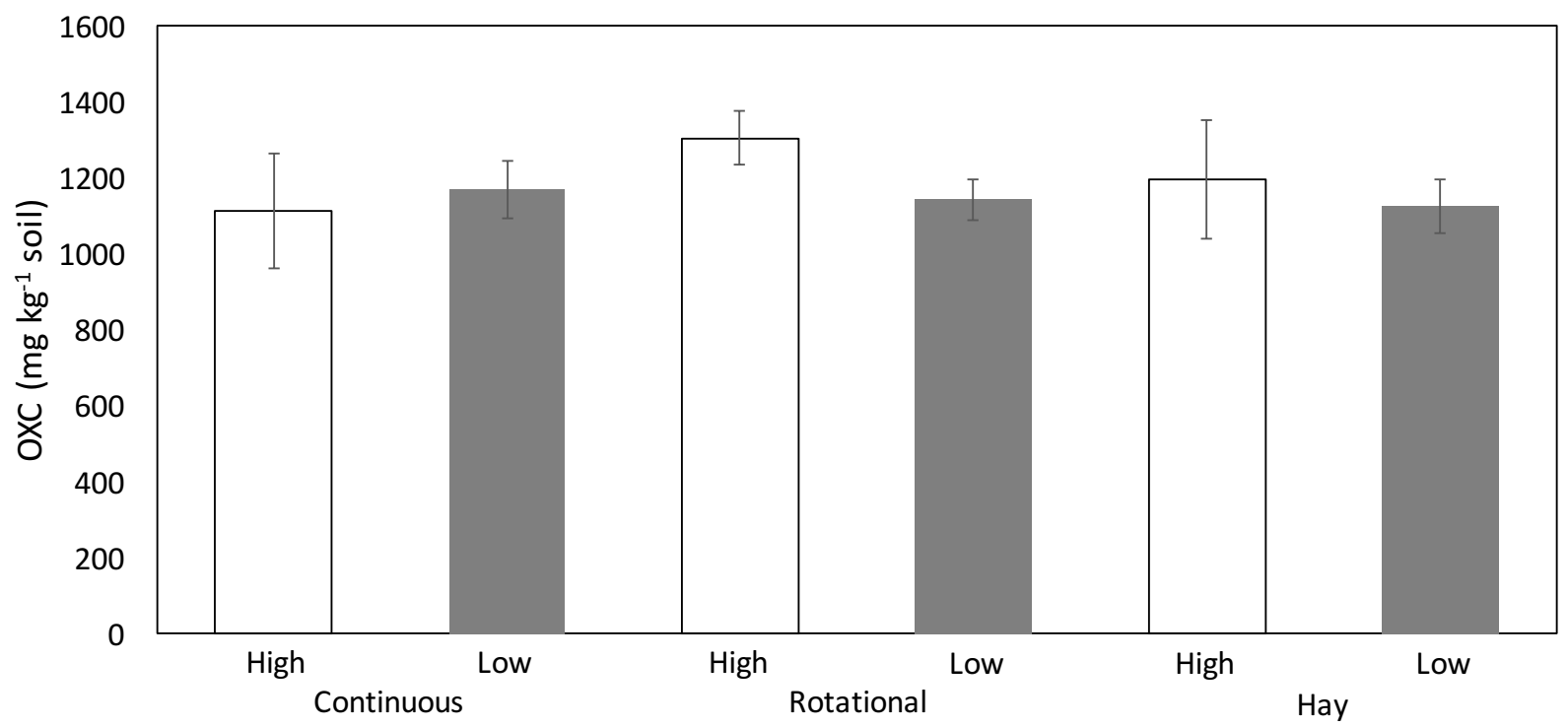

Figure 6: Oxidizable carbon $(\mathrm{OXC})$ at $\mathrm{RV}$ following two years of defoliation frequency and severity treatments. Bars represent $\pm 1 \mathrm{SE}(n=9)$.

\section{Defoliation effects on microbial enzyme activity}

To determine the impact of pasture defoliation frequency and severity on the microbial potential to degrade cellulose, the activity of the microbial extracellular enzyme $\beta$-glucosidase (BG) was measured. At OF, BG exhibited a significant defoliation frequency $\times$ severity interaction (Figure 7, p =0.04). Student's t-test determined simulated rotational stocking at low severity exhibited the lowest BG activity $(\mathrm{p}<0.10)$, whereas continuous stocking low severity, rotational high severity, and hay high severity all exhibited the greatest BG activity. At RV, BG activity was not affected by defoliation frequency nor severity (Figure 7, p = 0.96). 

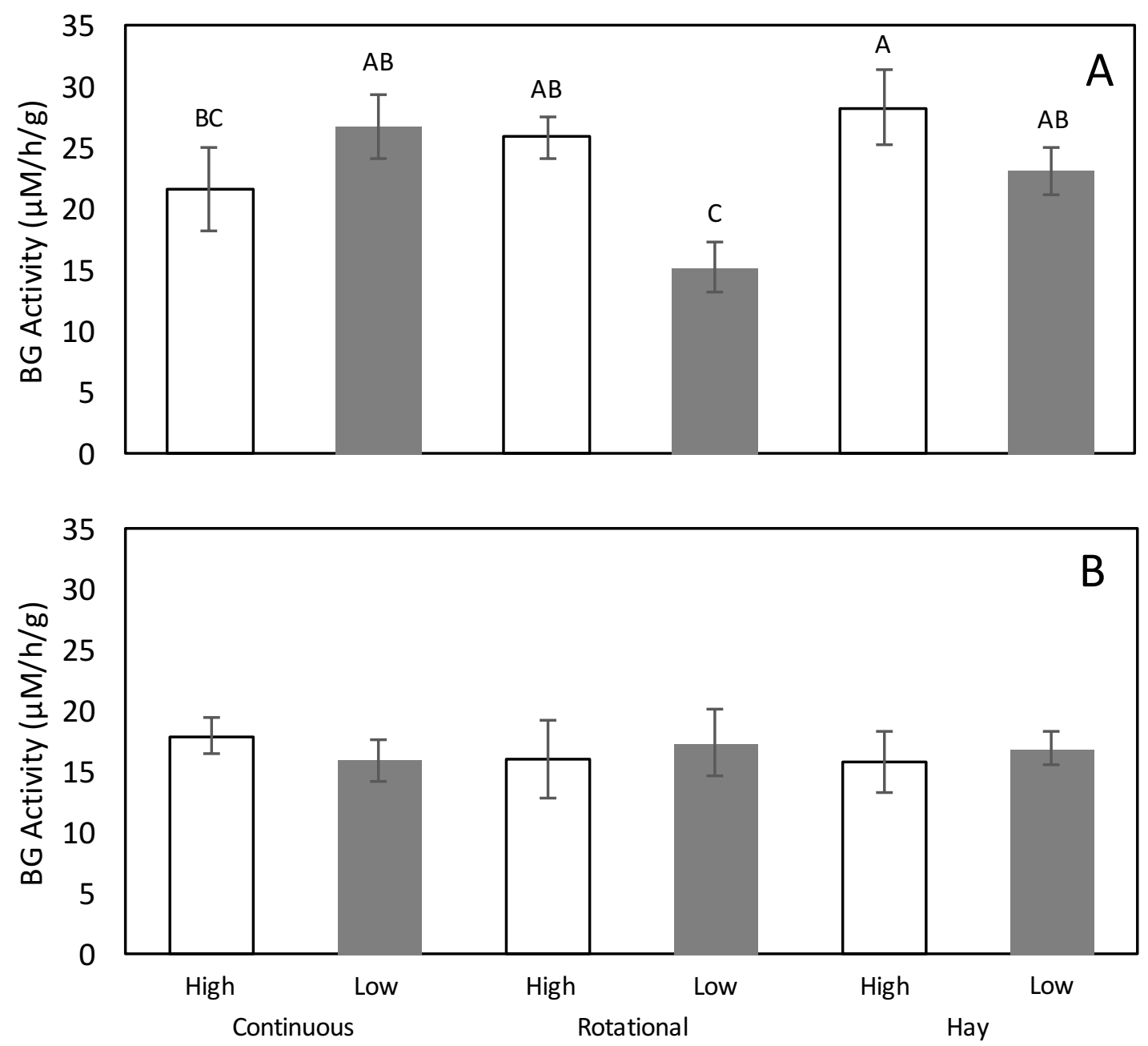

Figure 7: Mean $\beta$-glucosidase (BG) activity by defoliation treatment at OF (A) and RV (B) following two years of defoliation treatments. Open bars represent high severity clipping. Solid bars represent low severity clipping. There was a significant frequency $\times$ severity interaction at $\mathrm{OF}$, but no significant frequency effect, severity effect or frequency $\times$ severity interaction at RV. Bars represent means $\pm 1 \mathrm{SE}(\mathrm{n}=3)$. Letters separate means.

To identify differences in microbial $\mathrm{N}$ acquisition potential due to defoliation frequency and severity, $\beta$ - $N$-acetylglucosaminidase (NAG) activity was quantified. NAG activity was not impacted at either site due to defoliation frequency (OF $p=0.52 ; \mathrm{RV} p=0.92)$ nor severity (OF $\mathrm{p}=0.78 ; \mathrm{RV} \mathrm{p}=0.22)$, and there was not a significant frequency $\times$ severity interaction $(\mathrm{OF} p=$ 0.67 ; R p $=0.60)$. Though non-significant, at $\mathrm{OF}$, hay stocking frequency at low severity did exhibit a $48 \%$ greater NAG activity compared to all other treatments. At RV, the continuous 
frequency high severity treatment had approximately $45 \%$ greater NAG activity compared to all other treatments, though this response was not significant.

To identify differences in microbial $\mathrm{P}$ acquisition due to defoliation strategy, AP activity was quantified. At both OF and RV, AP activity was not impacted by defoliation frequency (OF $\mathrm{p}=0.48 ; \mathrm{RV} \mathrm{p}=0.60)$ nor severity $(\mathrm{OF} \mathrm{p}=0.93 ; \mathrm{RV} \mathrm{p}=0.88)$, and there was no significant frequency $\times$ severity interactions $(\mathrm{OF} p=0.21, \mathrm{RV} p=0.24)$. Though non-significant, at OF AP activity was greatest in rotational frequency high severity plots, which exhibited a $20 \%$ greater activity than the next highest treatment (hay stage frequency high severity). At RV, rotational low severity exhibited the greatest AP activity, which though non-significant, was $24 \%$ greater than the average of all other treatments.

Defoliation impacts on microbial activity

Microbial activity, as defined by the combined activity of C-, N-, and P- acquiring enzymes, was significantly impacted by the defoliation treatments at OF, wherein the response was moderately significant for severity (PerMANOVA; severity effect; $p=0.06$; Figure 8 ), and not significant for defoliation frequency. Distance-based linear models were then used to test the impact of measured soil environmental parameters on microbial activity. At OF, marginal DistLM revealed that total C (19\% of variation explained), C:N (19\%), SOM content (17\%) and percent moisture (15\%) all accounted for a significant proportion of variation in microbial activity. The influence of $\mathrm{pH}$ and $\mathrm{OXC}$ were not significant. At $\mathrm{OF}$, best model selection revealed that a model including both SOM and C:N most parsimoniously accounted for the greatest variance in microbial activity across the treatments $\left(\right.$ Table $5, \mathrm{R}^{2}=0.32$, adjusted $\mathrm{R}^{2}=$ 0.22). At RV, there was no response of microbial activity to defoliation frequency nor severity 
(PerMANOVA main tests $\mathrm{P}>0.10$ ). However, despite there being no significant impact of defoliation frequency nor severity on microbial activity at RV, marginal DistLM revealed that total C (35\% of variation explained), percent moisture (18\%), C:N (15\%) and OXC (12\%) all accounted for a significant proportion of variation.

Table 5: Marginal Distance based linear model (DistLM) of microbial activity against environmental factors in OF and RV. Including the results of best model, which determines the maximum proportion of variance explained with minimum parameters.

\begin{tabular}{lcccc} 
& \multicolumn{2}{c}{ Organic Farm } & \multicolumn{2}{c}{ Reedsville Farm } \\
& $\begin{array}{c}\text { Pseudo- } \\
\text { F }\end{array}$ & $\begin{array}{c}\text { Prop. of Variation } \\
(\%)\end{array}$ & $\begin{array}{c}\text { Pseudo- } \\
\text { F }\end{array}$ & $\begin{array}{c}\text { Prop. of Variation } \\
(\%)\end{array}$ \\
\hline $\mathrm{pH}$ & 1.4 & 8 & 0.9 & 5 \\
$\%$ Moisture & $2.7^{*}$ & 15 & $3.4^{*}$ & $18^{\&}$ \\
$\%$ SOM & $3.2^{*}$ & $17^{\&}$ & 1.1 & 6 \\
Total C & $3.7^{*}$ & 19 & $8.6^{*}$ & $35^{\&}$ \\
C:N & $3.6^{*}$ & $19^{\&}$ & $2.9^{*}$ & 15 \\
OXC & 1.5 & 9 & $2.3^{*}$ & $12^{\&}$ \\
\hline $\begin{array}{l}\text { Best Model Power } \\
\left(\mathrm{R}^{2}\right)\end{array}$ & & 0.31 & & 0.49 \\
\hline
\end{tabular}

$* \mathrm{P}<0.10$

\&parameter included in "best" model selection 

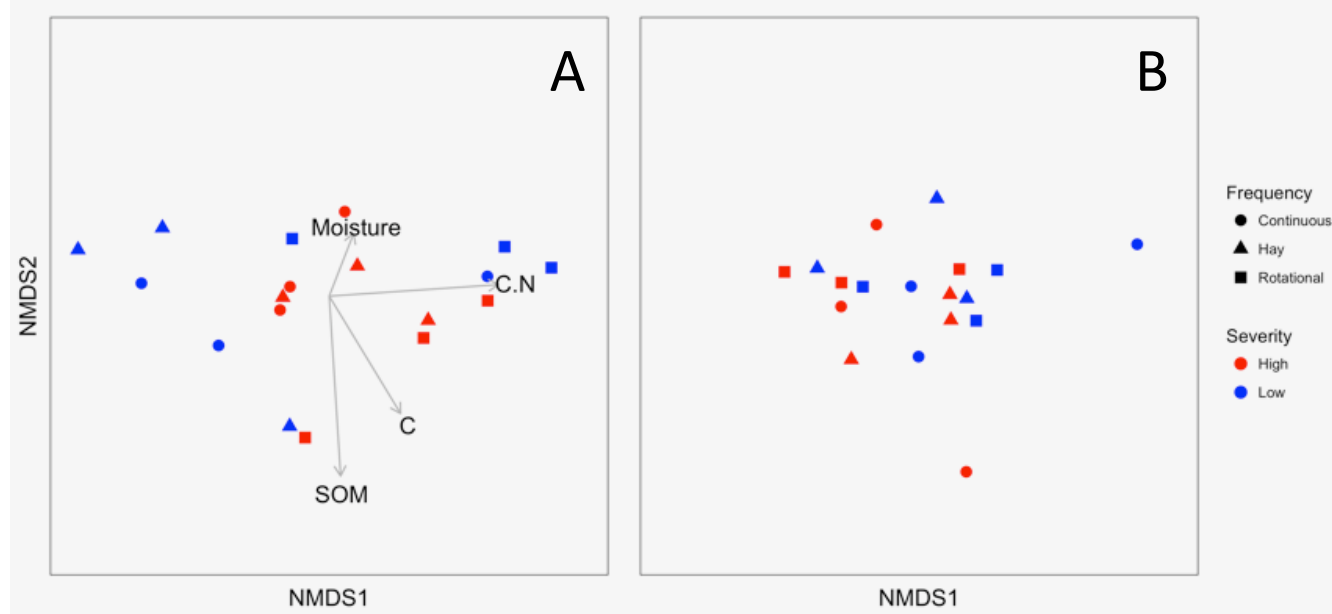

Figure 8: Non-metric multidimensional scaling plots of microbial activity at OF (A) and RV (B). At OF, microbial activity was significantly impacted by defoliation severity $(p<0.05)$, but not defoliation frequency. No effect of defoliation was apparent at RV. Vectors in plot A indicate influence of environmental parameters deemed significant by marginal DistLM on microbial activity. Parameter vectors were not displayed for panel B, because no significant defoliation effect was detected.

\section{$\underline{\text { Legacy effects on pasture canopy due to defoliation }}$}

To determine whether legacy effects exist due to defoliation treatment on forage, LAI was recorded at the beginning of the following growing season in May 2018. Indeed, significant differences due to defoliation frequency at OF and RV were observed (Figure 9, $\mathrm{p}<0.01$ and $=$ 0.05 , respectively). At OF, continuous frequency plots had $\sim 50 \%$ greater LAI than either rotational or hay frequency plots, but at RV continuous stocking had $\sim 25 \%$ lower LAI than either rotational or hay. 

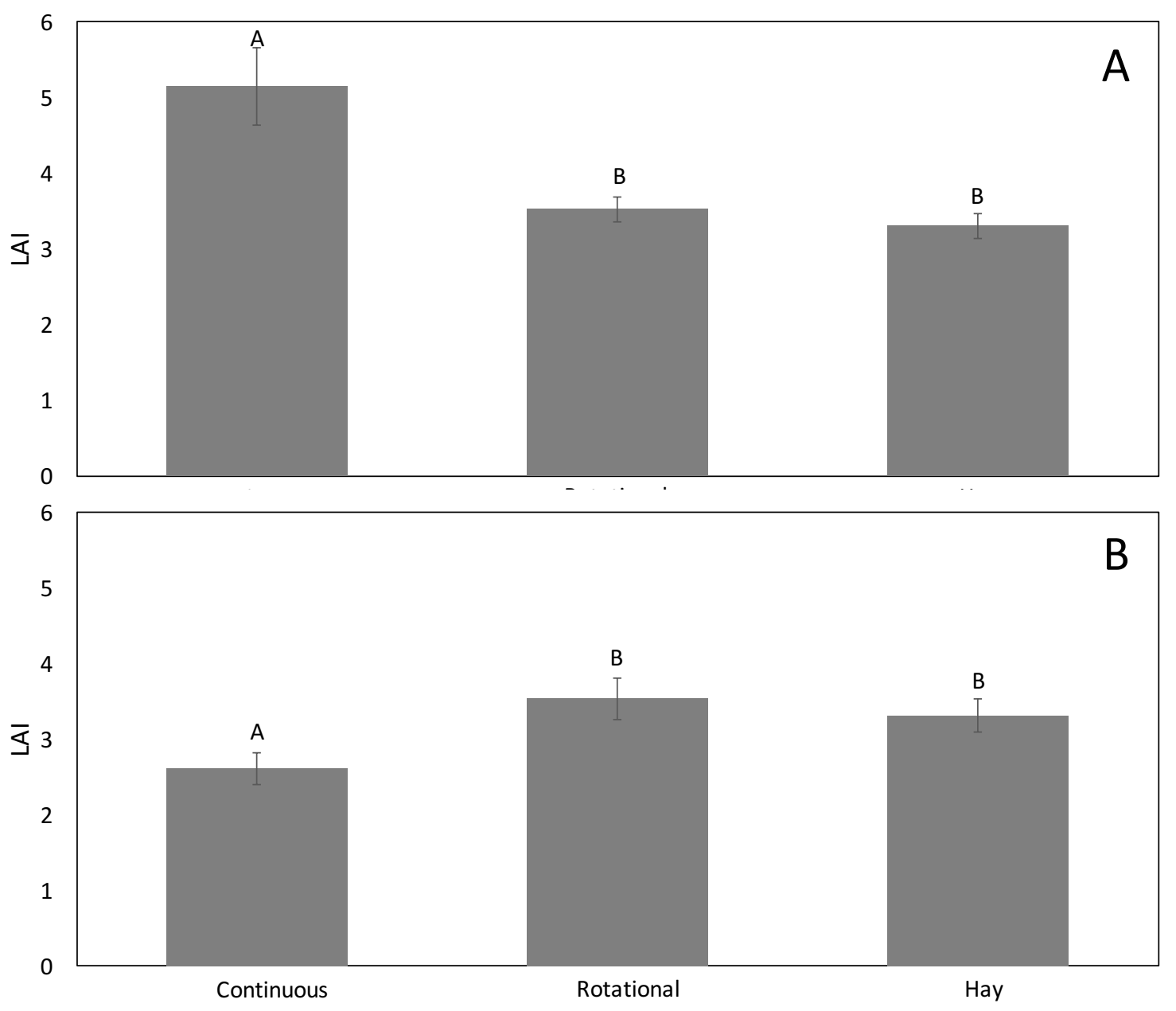

Figure 9: OF (A) and RV (B) LAI at the beginning of the third year of pasture defoliation treatments. At OF and RV, a defoliation frequency effect was detected $(p<0.01$ and $p=0.05$, respectively) no significant defoliation severity effect nor a frequency $\times$ severity interaction was exhibited at either site. Bars represent means $\pm 1 \mathrm{SE}(\mathrm{p}=0.05, \mathrm{n}=6)$. Letters separate means.

\section{Discussion}

My hypothesis that moderate defoliation management strategy would significantly affect soil $\mathrm{C}$ stocks and the activity of microbial extracellular enzyme activity associated with microbial $\mathrm{C}$ acquisition was partially supported, as BG activity was reduced in the rotational-low severity and C stocks were only significantly altered by defoliation severity (Figure 5) at OF, but not RV. In addition, my prediction that enzymes associated with $\mathrm{N}$ and $\mathrm{P}$ would be increased 
with greater soil $\mathrm{C}$ was not supported. For example, at $\mathrm{OF}, \mathrm{BG}$ activity (a C-obtaining enzyme) was significantly reduced $(-38 \%)$ in rotational low severity treatments, suggesting that the microbial capacity to mineralize $\mathrm{C}$ from $\mathrm{SOM}$ is reduced in this moderate-to-low frequency and severity treatment combination. Extracellular enzyme activities related to $\mathrm{N}$ and $\mathrm{P}$ were not different across defoliation treatments. Indeed, it is well established that grazing can impact microbial C dynamics $(63,64)$, however this is the first assessment of such changes in Central Appalachian pastures. These results demonstrate that defoliation frequency and severity can significantly impact C-associated extracellular enzyme activities in relatively short time scales, in this case only two years. This is shorter to other assessments of grazing impacts on soil enzyme activity, wherein significant effects were observed after 5 years of treatments (65).

Results from this study indicate that pasture defoliation can lead to changes in soil C availability $(35,39)$. This response has also been shown in other studies, for example, in grasslands, defoliation resulted in greater exudation of low molecular weight $\mathrm{C}$ molecules from roots $(8,66-69)$. At $\mathrm{OF}$, greater oxidizable $\mathrm{C}$ availability when defoliation events were less severe, however at $\mathrm{RV}$ there was no discernible pattern in $\mathrm{OXC}$ in relation to defoliation management strategy. Thus, it is possible that organically managed systems are more amenable to management-induced changes in soil nutrient dynamics. A meta-analysis found that organically managed farms sequester more soil C compared to conventionally managed farms (70). Quantitatively, organic management was shown to increase mineral-associated organic matter as much as $40 \%$ compared to conventional management $(71,72)$. The findings here and the results of others shown above might suggest greater microbial nutrient mineralization in organic farms, however further comparisons of defoliation impact in organic and conventional 
systems using replicated experimental designs are needed to properly test whether this observation is indicative of a larger phenomenon.

In this study, less severe pasture defoliation management strategies led to significant differences in labile soil $\mathrm{C}$ pools at both $\mathrm{OF}$ and $\mathrm{RV}$, but not more temporally stable $\mathrm{C}$ pools as indicated by no significant differences in total soil $\mathrm{C}$ and SOM content due to defoliation treatments. Three mechanisms by which defoliation increases SOC have been identified: changes in the allocation of net primary production (NPP) to soil (i.e. root exudates), changes in soil organic $\mathrm{N}$ stocks, and the alteration of SOM decomposition (73). For example, grazing can increase SOC via increased NPP allocation to root exudates $(8,63,66)$ and by facilitating the mechanical breakdown of plant materials prior to decomposition by soil microbes $(43,74)$. It is apparent that differences in defoliation management could induce changes in total SOC via small changes in root exudation or alteration of decomposition, however these changes often take many years or even decades to manifest $(43,74,75)$. In this study, greater OXC was exhibited in less severely defoliated plots after two growing seasons, which suggests that defoliation management differences could result in greater SOC in our study sites.

Counter to my hypothesis, despite significant difference in OXC across defoliation management treatments, there were no significant differences in AP and NAG activity. NAG and $\mathrm{AP}$ are $\mathrm{N}$ and $\mathrm{P}$ acquiring enzymes and considered to be important indicators of microbial nutrient demands $(2,56)$. This may be because neither nitrogen nor phosphorus were limiting due to the use of fertilizers at OF (2). In addition, defoliation has been shown to increase belowground $\mathrm{N}$ and $\mathrm{P}$ allocation, which may increase cycling and availability of $\mathrm{N}$ and $\mathrm{P}$ to the microbial community reducing microbial nutrient foraging (76). Finally, the results shown here do not indicate that reduced $\mathrm{C}$ demands resulted in increased nutrient foraging. 
Microbial activity, as indicated by the combined activities of extracellular enzymes associated with $\mathrm{C}, \mathrm{N}$, and $\mathrm{P}$ acquisition, was responsive to defoliation severity but not frequency at $\mathrm{OF}$, and it was not responsive to severity nor frequency at RV. Environmental parameters that parsimoniously accounted for the greatest variation in microbial activity differed between sites, but each had significant proportions of variation due to parameters related to $\mathrm{C}$. These data demonstrate that microbial activity is dependent on soil parameters, particularly those related to soil C and can vary with management strategy. These results are in concordance with other findings. For example, microbial activity positively correlated with soil C pools in grazed pastures and further, increased grazing severity reduced soil C (24). In addition, microbial activity and important soil parameters (i.e. $\mathrm{pH}$, soil moisture, and total $\mathrm{C}$ ) were greater under less severe grazing in an Indian pasture (77). In this study, microbial activity responded differently to defoliation treatments and soil parameters in an organically and conventionally, this has been exhibited previously (78). However, because of inherent differences between sites, accurate assessments of organic versus conventional standards cannot be made and would be an interesting topic of future research. Nonetheless, results shown here suggest that defoliation management is capable of inducing changes in microbial activity.

In this study, pasture defoliation increased legacy light capture at both sites (Figure 9), which aligns with the findings of previous studies $(12,30,79,80)$. At OF, utilization was greatest in the continuously defoliated plots, whereas at RV, utilization was lowest in the continuously defoliated plots. Given that mean annual precipitation and temperature are higher at OF as compared to RV (Table 1), these differences may be due to forage experiencing greater stress at RV where precipitation and temperature were more limiting and possibly prevented luxuriant compensatory regrowth following frequent defoliation (12). At OF, the increased 
oxidizable $\mathrm{C}$ content in plots experiencing lower defoliation severity may be associated with greater light capture following defoliation events or it may be due to reduced stress on the plant to recover lost leaf area (12). In addition, the differences in LAI due to defoliation frequency were more pronounced at the beginning of the third year of treatments, which suggests the differences in canopy development may become more pronounced with time. While treatment differences in LAI were observed, all LAI measurements recorded were within the suggested acceptable range of LAI for pasture $(\sim 3-5,81)$.

\section{Conclusion}

Overall, the results of this study demonstrated that defoliation management strategy can induce a top-down ecological effect on forage utilization and light-capture efficiency, soil C availability and extracellular enzyme activity, which may have long-lasting impacts on soil C stocks. Enzyme activities related to microbial $\mathrm{N}$ and $\mathrm{P}$ acquisition were unaffected by the defoliation treatments, which is plausibly due to the use of N- and P-rich fertilizer. These results do not necessarily conform to previous research on the effects of greater C availability to soil, but this is most likely because neither $\mathrm{N}$ nor $\mathrm{P}$ were limiting in our experimental plots. In future studies, examining the impacts of defoliation management with and without fertilizer addition may reveal novel microbial responses to this selective pressure. For example, if defoliation increases root exudates and reduces the need to acquire $\mathrm{C}$, more resources may be devoted to acquiring $\mathrm{N}$ or $\mathrm{P}$ resulting in greater NAG and $\mathrm{AP}$ activities if $\mathrm{N}$ and $\mathrm{P}$ are indeed limiting. In addition, because grazing introduces environmental fluxes that were not introduced in this study (e.g. nutrient hot spots and soil compaction from animals) our study is limited in its explanatory 
power and future studies should include the presence of either grazing livestock or simulated excreta and soil compaction. 


\title{
Chapter 2: Greater soil carbon increases nitrous oxide emission potential in two West Virginia pastures
}

\author{
Abstract \\ Nitrous oxide $\left(\mathrm{N}_{2} \mathrm{O}\right)$ is a potent greenhouse gas and its emission from soil is largely \\ controlled by biogeochemical processes, which can be altered via land management. Proper \\ management of agricultural soils, specifically those used for grazing which account for over 600 \\ million acres of land in the U.S., can significantly reduce $\mathrm{N}_{2} \mathrm{O}$ emissions. The aim of this study is \\ to investigate how defoliation management strategies affect below-ground parameters such as \\ soil organic matter (SOM) production, as well as the abundance of microbial functional guilds \\ associated with the nitrogen cycle, which I use to predict potential emissions of a pervasive \\ greenhouse gas, namely, $\mathrm{N}_{2} \mathrm{O}$. Soil microbial activity is mainly dependent on environmental \\ factors such as $\mathrm{pH}$, soil moisture, and carbon (C) availability. If defoliation alters these soil \\ parameters, then greater potential for $\mathrm{N}_{2} \mathrm{O}$ emissions could occur. I hypothesize that the greatest \\ $\mathrm{N}_{2} \mathrm{O}$ emission potential will come from experimental plots that are defoliated in a rotational \\ frequency (i.e. monthly) at a high severity (i.e., low forage height), due to greater below-ground \\ $\mathrm{C}$ availability that will stimulate microbial activity and incomplete denitrification. To address \\ this hypothesis, I implemented forage defoliation treatments of increasing intensity and \\ frequency in experimental plots at two West Virginia University Research Farms since July \\ 2016. After two full growing seasons, I assessed soil physical and chemical parameters, as well \\ as $\mathrm{N}_{2} \mathrm{O}$ emission potential as estimated by the quantifying the abundance of the bacterial genes \\ nirK and nos $Z$, the former being associated with nitrite reduction and the latter associated with \\ $\mathrm{N}_{2} \mathrm{O}$ reduction. At the Reedsville site, continuous grazing reduced potential $\mathrm{N}_{2} \mathrm{O}$ emissions to \\ only $28 \%$ of $\mathrm{N}_{2} \mathrm{O}$ emission potential from either rotational or hay defoliation frequencies. While \\ at the Organic Farm, $\mathrm{N}_{2} \mathrm{O}$ emissions were reduced by $45 \%$ under high severity defoliation. These \\ data will inform our understanding of the below-ground impacts of grazing and allow us to \\ develop a more effective management plan for livestock grazing of $\mathrm{C}_{3}$ perennial grasses to \\ reduce $\mathrm{N}_{2} \mathrm{O}$ emissions from Central Appalachian pastures.
}




\section{Introduction}

Nitrous oxide $\left(\mathrm{N}_{2} \mathrm{O}\right)$ is a potent greenhouse gas with a climate warming potential 298 times that of carbon dioxide $\left(\mathrm{CO}_{2}\right)$, it is also associated with ozone depletion (82).

Anthropogenic $\mathrm{N}_{2} \mathrm{O}$ emissions mainly come from agricultural land, which are estimated to account for $54 \%$ of global $\mathrm{N}_{2} \mathrm{O}$ emissions (83). Further, $\mathrm{N}_{2} \mathrm{O}$ emissions are increasing at a rate of $0.3 \%$ annually (83). This increase in $\mathrm{N}_{2} \mathrm{O}$ emissions is at least partially due to land management practices aimed to increase crop yields (84), while neglecting to manage for environmental sustainability $(85,86)$. Proper management of agricultural soils, specifically the 242 million hectares of land in the U.S. that are currently used as pasture for grazing livestock, can significantly reduce $\mathrm{N}_{2} \mathrm{O}$ emissions $(9,87-89)$. For example, no-till pastures have reduced $\mathrm{N}_{2} \mathrm{O}$ emissions and greater soil carbon (C) storage, but it also reduces yield $(90,91)$. To inform the development of best management practices (BMP), it is necessary to understand how forage management strategies may affect microbial functional guilds that are associated with the production of $\mathrm{N}_{2} \mathrm{O}$, a potent greenhouse gas, which is the focus of this study.

$\mathrm{N}_{2} \mathrm{O}$ emissions are mainly the result of two microbial processes: nitrification and denitrification (92). Nitrification is an aerobic process that oxidizes ammonia $\left(\mathrm{NH}_{3}\right)$ to nitrate $\left(\mathrm{NO}_{3}{ }^{-}\right)$and denitrification is an anaerobic process that reduces nitrate $\left(\mathrm{NO}_{3}{ }^{-}\right)$or nitrite $\left(\mathrm{NO}_{2}{ }^{-}\right)$to gaseous $\mathrm{N}$ products $\left(\mathrm{NO}, \mathrm{N}_{2} \mathrm{O}\right.$, and $\left.\mathrm{N}_{2}\right)$. However, only denitrification is recognized as a significant biological consumer of $\mathrm{N}_{2} \mathrm{O}$, because $\mathrm{N}_{2} \mathrm{O}$ emissions from nitrification are often $<1 \%$ of total $\mathrm{N}_{2} \mathrm{O}$ emissions in agricultural systems, but values as high as $30 \%$ have been demonstrated (92-94). Current conceptual frameworks postulate that both distal and proximal controls affect $\mathrm{N}_{2} \mathrm{O}$ emissions $(92,95,96)$. For example, distal controls, including $\mathrm{C}$ substrate availability, $\mathrm{pH}$, temperature, $\mathrm{O}_{2}$ availability, plant community dynamics, and disturbance can influence microbial functional guilds associated with denitrification $(95,96)$. However, the rate 
and final products of denitrification are ultimately constrained by proximal controls that affect the metabolism of the denitrifying community and include: $\mathrm{O}_{2}$ and $\mathrm{C}$ availability, $\mathrm{pH}$, and temperature $(95,96)$. Therefore, $\mathrm{N}_{2} \mathrm{O}$ emissions can be affected by defoliation management via increases in organic $\mathrm{C}$, changes in $\mathrm{pH}$, and $\mathrm{O}_{2}$ availability, which alter the structure of the denitrifying community $(8,53,92,97-100)$. This conceptual framework, which links the $\mathrm{C}$ and nitrogen $(\mathrm{N})$ cycles, is known as the "hole-in-the-pipe model" $(92,101)$. Because the $\mathrm{C}$ and $\mathrm{N}$ cycles are inherently linked it is necessary to incorporate both cycles to effectively estimate the $\mathrm{N}_{2} \mathrm{O}$ emission potential associated with environmental changes (i.e. by pasture defoliation). Failure to recognize the coupled $\mathrm{N}$ and $\mathrm{C}$ cycles in agricultural land management could result in net increases of total GHG emissions and reduced environmental sustainability (102). For example, land management practices aimed to increase SOC are desirable to reduce atmospheric $\mathrm{CO}_{2}$ concentrations (103), however those increases in SOC could result in an unintended consequence of greater emissions of $\mathrm{N}_{2} \mathrm{O}(104)$.

It is plausible that pasture management strategies can alter the abundance of microbial functional guilds associated with denitrification, which in turn could increase or decrease the potential for $\mathrm{N}_{2} \mathrm{O}$ emissions. Differences in $\mathrm{pH}$, soil texture, and organic $\mathrm{C}$ can influence the composition and diversity of denitrifying communities in a variety of agricultural settings $(86,87$, $100,105,106)$. Further, defoliation and grazing can alter the soil microbial community via a topdown ecological cascade, whereby defoliation selects a grazing- tolerant plant community, which may increase root exudation of low molecular weight $\mathrm{C}$ molecules following defoliation events, fueling microbial activity $(8,17,35,48)$. However, how this cascade may affect the abundance of denitrifying bacteria and $\mathrm{N}_{2} \mathrm{O}$ emission potential is still unknown. Denitrification can be stimulated by the addition of labile root exudates, which can stimulate microbial activity and denitrification 
(20). In addition, organic farm standards can increase $\mathrm{N}_{2} \mathrm{O}$ emissions as well as the abundance of genes associated with denitrification as compared to conventional management standards (107). Importantly, $\mathrm{N}_{2} \mathrm{O}$ can be produced through an incomplete denitrification process. Under suboptimal conditions, an under-abundance of microbes that possess the nos $Z$ gene, which encodes an enzyme that reduces $\mathrm{N}_{2} \mathrm{O}$ to benign $\mathrm{N}_{2}$ gas, cannot sustain $\mathrm{N}_{2} \mathrm{O}$ reduction rates equal to rates of $\mathrm{N}_{2} \mathrm{O}$ production by bacteria harboring the nir $K$ gene. Hence, the microbial population may either serve as a sink (if $\mathrm{N}_{2} \mathrm{O}$ is reduced to $\mathrm{N}_{2}$ ) or a source of $\mathrm{N}_{2} \mathrm{O}$ emissions from soil (108).

The use of molecular techniques provides a means by which $\mathrm{N}_{2} \mathrm{O}$ emissions can be estimated. For example, the gene nirK encodes a nitrite reductase, which reduces $\mathrm{NO}_{2}{ }^{-}$to $\mathrm{N}_{2} \mathrm{O}$ (101, 109). In addition, the gene $n o s Z$ encodes a nitrous oxide reductase $\left(\mathrm{N}_{2} \mathrm{O} \rightarrow \mathrm{N}_{2} ; 6\right)$, which reduces the pollutant gas to an in inert form. In a recent meta-analysis, the abundances of nirK and nos $Z$ significantly correlated to their process rate in agricultural soils, suggesting that it is possible to estimate $\mathrm{N}_{2} \mathrm{O}$ emission rates from nirK and nos $Z$ gene abundances (111). Quantifying the genes most closely associated with $\mathrm{N}_{2} \mathrm{O}$ production and their relation to available $\mathrm{C}$ may provide valuable information to estimate the potential for $\mathrm{N}_{2} \mathrm{O}$ emission from pastures.

The objective of this study was to determine the impact of defoliation frequency and severity on the $\mathrm{N}_{2} \mathrm{O}$ emission potential of agricultural soils. I hypothesize that plots defoliated at a moderate frequency (rotational stocking) and low severity (clipped to $13 \mathrm{~cm}$ ) will have greater $\mathrm{C}$ bioavailability and consequently greater $\mathrm{N}_{2} \mathrm{O}$ emission potential. To address my hypothesis, six defoliation treatments were implemented at two West Virginia farms and qPCR was used to quantify the abundance of the genes nirK and nos $Z$ to estimate the potential $\mathrm{N}_{2} \mathrm{O}$ emissions due to defoliation management strategy (sensu 41, 42). 


\section{Methods}

\section{Site description}

This experiment was conducted at two West Virginia University (WVU) research farms: The Organic Research Farm in Morgantown, WV (395N, -7994W; hereafter “OF”) and the JW Ruby Research Farm in Reedsville, WV (39¹N, -7982W; hereafter "RV"; Table 6). The OF was organically certified in 1998, and the RV site is conventionally managed. Soils at OF and RV consist of Dormont silt loam and Latham silt loam, respectively. Mean annual temperature (MAT) and mean annual precipitation (MAP) are $20.3^{\circ} \mathrm{C}$ and $125.5 \mathrm{~cm}$, respectively, at $\mathrm{OF}$ and $12^{\circ} \mathrm{C}$ and $153 \mathrm{~cm}$ at RV. Experimental plots were established at each site in June 2016, plots measured $7 \mathrm{~m} \times 3 \mathrm{~m}$ at $\mathrm{OF}$ and $8 \mathrm{~m} \times 3 \mathrm{~m}$ at RV. On July 1, 2016, six experimental defoliation treatments consisting of three simulated frequency regimes at two levels of severity were implemented at each site (Table 7) in a randomized block design ( 3 frequency levels $\times 2$ severity levels $\times 3$ blocks $\times 2$ sites $=36$ total plots). The simulated frequency and severity treatments were selected to align with common pasture management strategies in the Central Appalachian region, representing continuous, rotational, and hay-stage pasture management as suggested by the United States Department of Agriculture Natural Resources Conservation Service (50). The continuous frequency treatment was defoliated every 7-10 days, rotational frequency plots were defoliated every 28-35 days, and hay-stage plots were defoliated every 42-45 days. Each simulated frequency treatment was also defoliated to two heights to represent low and high severity defoliation, respectively; the defoliation height was 6-8 $\mathrm{cm}$ for the high severity treatment and $13 \mathrm{~cm}$ for the low severity treatment. Simulated defoliation was achieved by clipping vegetation using a Monarch Sickle-Bar Mower outfit with a 36-inch serrated sickle bar (Jari USA, St. Peter, Minnesota). 
Table 6: Summary characteristics of each experimental site in West Virginia.

\section{Organic Farm}

Reedsville

\begin{tabular}{lcc}
\hline Coordinates & $39^{\circ} 5 \mathrm{~N},-79^{\circ} 94 \mathrm{~W}$ & $39^{\circ} 1 \mathrm{~N},-79^{\circ} 82 \mathrm{~W}$ \\
Soil Series & Dormont Silt Loam & Latham Silt Loam \\
Management & Organic & Conventional \\
MAP (51) & $125.5 \mathrm{~cm}$ & $153.0 \mathrm{~cm}$ \\
MAT(51) & $20.3^{\circ} \mathrm{C}$ & $12^{\circ} \mathrm{C}$ \\
Relative N/P/K & High/Low $/ \mathrm{High}$ & $\mathrm{High} / \mathrm{High} / \mathrm{Low}$ \\
\hline
\end{tabular}

Table 7: The six experimental treatments included in this experiment by stocking rate and clipped stubble height.

A

B

$\mathrm{C}$

$\mathrm{D}$

$\mathrm{E}$

$\mathrm{F}$

\begin{tabular}{lcccccc}
\hline Stocking & Rotational & Rotational & Continuous & Continuous & Hay & Hay \\
Clip Height & $6 \mathrm{~cm}$ & $13 \mathrm{~cm}$ & $8 \mathrm{~cm}$ & $13 \mathrm{~cm}$ & $6 \mathrm{~cm}$ & $13 \mathrm{~cm}$ \\
\hline
\end{tabular}

$\underline{\text { Soil Sampling }}$

Soil samples were collected following two years of defoliation treatments on November

7, 2017. Plots were randomly sampled 10 times using a soil probe $(1.7 \mathrm{~cm}$ diameter $)$ to a depth

of $7.5 \mathrm{~cm}$. The cores were then thoroughly homogenized by hand to produce one composite sample per plot. The homogenized soil samples were stored on ice in the field and returned to the lab within two hours of sampling. Upon return to the lab, each soil sample was sieved $(2,000$ 
$\mu \mathrm{m})$ to remove coarse roots and rocks. Homogenized sieved soil was stored at $-20{ }^{\circ} \mathrm{C}$ for molecular analysis.

\section{Soil Physiochemical Characteristics}

To determine the impact of defoliation on soil properties, soil physiochemical characteristics were assayed that have been shown to impact both plant and microbial function

were $\mathrm{pH}$, soil moisture, total $\mathrm{C}$, total $\mathrm{N}$, soil organic matter content, and permanganate oxidizable C content (i.e., labile C; $(2,32,42,53)$,. Soil pH was measured using an Accumet AE 150 probe (Fisher Scientific, Hampton, $\mathrm{NH}$ ) in a 1:5 soil:0.01 $\mathrm{M} \mathrm{CaCl}_{2}$ slurry (54). The moisture content of soil samples was determined gravimetrically, whereby $10 \mathrm{~g}$ of field-moist soil was dried at $105^{\circ} \mathrm{C}$ for 24 hours. Following drying, samples were re-weighed to determine dry mass and then combusted at $505{ }^{\circ} \mathrm{C}$ for 6 hours to determine percent soil organic matter (SOM) content by loss on ignition (LOI). The amount of labile $\mathrm{C}$ was estimated by the permanganate oxidizable $\mathrm{C}$ method (55), whereby four analytical replicates of each sample were assayed using clear 96-well plates (Corning, Corning, NY) on a Synergy HTX plate reader (Biotek, Winooski, VT). Absorbance was recorded at $550 \mathrm{~nm}$. The total $\mathrm{C}$ and $\mathrm{N}$ content of the soil was determined by combustion analysis in a Carlo Erba 1500 NCS (Carlo Erba, St. Joseph, MI) using 12 mg of dry ground soil.

\section{DNA Extraction}

Total DNA was extracted from $1.0 \mathrm{~g}$ of field weight homogenized soil using the DNeasy Powerlyzer Powersoil ${ }^{\circledR}$ kit (QIAGEN, Hilden, Germany) according to the manufacturer’s 
protocol. Each sample was extracted in duplicate and combined after elution. DNA extraction quality and quantity were assessed on a NanoDrop One (Thermo Fisher, Scientific, Waltham, MA) and QuBit (Life Technologies, Carlsbad, CA) spectrophotometers, respectively, following manufacturer's protocol.

\section{Quantitative Polymerase Chain Reaction (qPCR)}

To determine how pasture management impacts soil $\mathrm{N}_{2} \mathrm{O}$ emission potential, I quantified the abundance of microbial genes associated with nitrification (nirK and nosZ) by quantitative polymerase chain reaction (qPCR). These genes are relevant for estimating $\mathrm{N}_{2} \mathrm{O}$ emission potential, as the nirK (copper-containing nitrite reductase) encodes an enzyme that reduces $\mathrm{NO}_{2}{ }^{-}$ to $\mathrm{N}_{2} \mathrm{O}$ (101), whereas the enzyme encoded by $\operatorname{nos} Z$ (nitrous oxide reductase) reduces $\mathrm{N}_{2} \mathrm{O}$ to $\mathrm{N}_{2}$ $(11,101,112)$. Thus, a greater ratio of $\operatorname{nirK} / \operatorname{nos} Z$ would indicate a greater $\mathrm{N}_{2} \mathrm{O}$ emission potential by the soil microbial community. All qPCR reactions were performed on a QuantStudio5 real-time PCR machine (Applied Biosystems, Foster City, CA) using TemPlate ${ }^{\circledR}$ 384-well PCR plates and TemPlate ${ }^{\circledR}$ RT Select Optical film (USA Scientific, Orlando, FL).

Primers nirK876 and nirK1040 (101) were used for the quantitation of the nirK gene and the primers nosZ2R and nosZ2F were used for the quantification of the nos $Z$ gene (Figure 10 and Table 8, (110)). For standard curve generation, PCRs were performed using each primer set on an environmental soil sample, and the resulting products were purified using ExoSAP-IT (Thermo Fisher, Waltham, MA) and used template DNA in qPCR reactions. The copy number of each PCR product in the standard was calculated based on the DNA concentration $\left(n g{ }^{\prime} \mu \mathrm{L}^{-1}\right)$ of the sample as determined by Qubit, divided by the mass of the PCR product assuming a mass of 325 Daltons per nucleotide (114). For qPCR, a $10 \mu \mathrm{L}$ final reaction volume was used, containing 
$2 \mu \mathrm{L}$ of molecular grade water (Mediatech Inc., Manassas, VA), $0.5 \mu \mathrm{L}$ of each primer (total primer concentration $=500 \mathrm{nM}$ ), $5 \mu \mathrm{L}$ of LUNA qPCR $2 \mathrm{X}$ master mix (New England Biolabs, Ipswich, MA), and $2 \mu \mathrm{L}$ of template DNA. For all functional genes, real time amplification was performed using the following program: 1 cycle at $95{ }^{\circ} \mathrm{C}$ for 5 minutes, 35 cycles at $95{ }^{\circ} \mathrm{C}$ for 20 s and $60{ }^{\circ} \mathrm{C}$ for $45 \mathrm{~s}, 1$ cycle at $95^{\circ} \mathrm{C}$ for $15 \mathrm{~s}$. To assess the quality of the PCR reaction a meltcurve was performed.

$\underline{\text { Statistical Analysis }}$

All statistical analyses were performed in SAS JMP (Version 13, SAS Institute Inc., Cary, NC). An ANOVA was first used to test for differences across sampling locations. A twoway analysis of variance (ANOVA) was performed on each parameter and tested two main effects (severity and frequency) and their interaction (frequency $\times$ severity). If a significant interaction was detected, a Student's T-test was used to determine differences among treatment means. Results were considered significant at $\alpha<0.05$ and marginally significant at $\alpha<0.10$. Associations between denitrification-associated functional genes and soil C parameters were determined using the general linear model in StatPlus (115) 


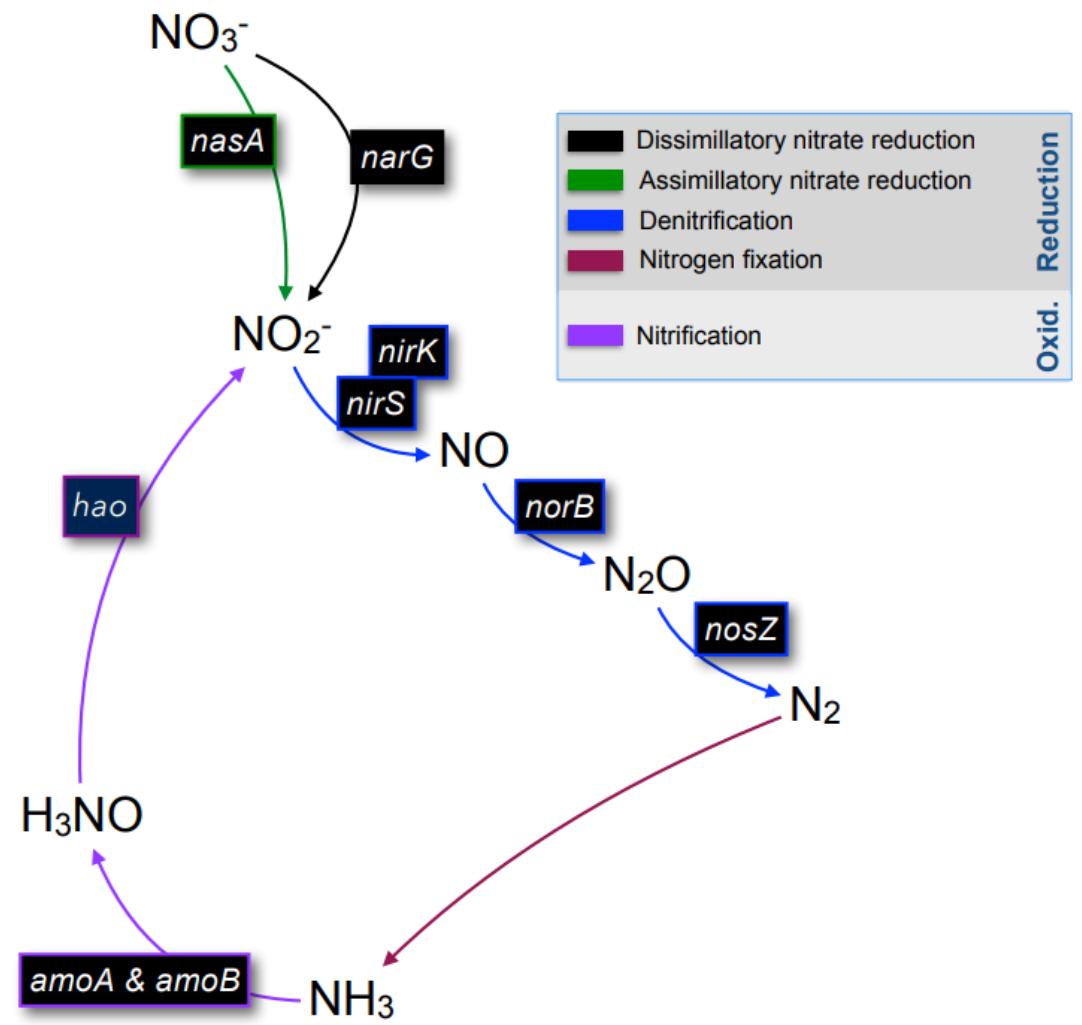

Figure 10: Genes associated with the production of enzymes facilitating nitrogen cycle transformations. This study focused on two genes: nirK and nos $Z$.

Table 8: Target genes and corresponding primer sequences with reference.

\begin{tabular}{llll}
\hline Target Gene & Primer & Sequence & Reference \\
\hline nirK & nirK.876 & ATYGGCGGVAYGGCGA & $(101)$ \\
nirK & nirK.1040 & GCCTCGATCAGRTTRTGGTT & $(101)$ \\
nosZ & NosZ2F & CGCRACGGCAASAAGGTSMSSGT & $(110)$ \\
nosZ & NosZ2R & CAKRTGCAKSGCRTGGCAGAA & $(110)$ \\
\hline
\end{tabular}




\section{Results}

$\underline{\text { Differences between sites following defoliation implementation }}$

The OF and RV farms were chosen as sites for this experiment due to their unique management practices (i.e., organic vs. conventional) as well as soil physico-chemical properties. For example, average oxidizable $\mathrm{C}$, soil organic matter content, soil $\mathrm{C}: \mathrm{N}$, acid phosphatase activity, NAG activity, $\mathrm{pH}$, and \% soil moisture were all significantly different between the two sites (Table 9). Soils at RV exhibited greater C:N soil organic matter and oxidizable C content, as well as reduced activities of microbial enzyme as compared to soils at OF.

Table 9: Differences in microbial enzyme and soil parameters at each site. (a) and (b) represent differences between the two sites at $p<0.05$.

\begin{tabular}{llll}
\hline Parameter & OF & RV & SE \\
\hline Soil moisture (\%) & 29.3 & 29.0 & 0.4 \\
$\mathrm{pH}$ & $6.0(\mathrm{a})$ & $6.4(\mathrm{~b})$ & 0.06 \\
Total C & $2.5(\mathrm{a})$ & $3.3(\mathrm{~b})$ & .09 \\
Total N & $0.27(\mathrm{a})$ & $0.34(\mathrm{~b})$ & .007 \\
Soil C:N & $8.83(\mathrm{a})$ & $9.9(\mathrm{~b})$ & 0.2 \\
SOM (\%) & $8.00(\mathrm{a})$ & $9.8(\mathrm{~b})$ & 0.1 \\
Oxidizable C (mg kg $\left.{ }^{-1}\right)$ & $782.9(\mathrm{a})$ & $1175.5(\mathrm{~b})$ & 48.5 \\
$\beta$-glucosidase & $23.5(\mathrm{a})$ & $16.7(\mathrm{~b})$ & 1.2 \\
$\beta$-N- & $17.2(\mathrm{a})$ & $7.3(\mathrm{~b})$ & 1.3 \\
acetylglucosaminidase & & & 2.8 \\
Acid Phosphatase & $23.5(\mathrm{a})$ & $49.7(\mathrm{~b})$ & \\
\hline
\end{tabular}

To determine differences in soil $\mathrm{C}$ storage and availability SOM, C:N, and OXC were measured. SOM was not significantly different due to defoliation treatment at either site SOM averaged $8.0 \%$ at $\mathrm{OF}$ and $9.8 \%$ at RV. Soil C:N was not different across all defoliation treatments. Soil C:N average 8.8 at OF and 9.9 at RV. Oxidizable C averaged 820.1 and 1175.5 
$\mathrm{mg} \mathrm{kg}^{-1}$ soil at OF and RV, respectively. Moderately significant defoliation frequency and intensity effects on $\mathrm{OXC}$ were detected at $\mathrm{OF}(\mathrm{p}=0.06$ and 0.09 , respectively), whereas no significant defoliation effect was detected at RV. At OF, oxidizable C values were always greater under low defoliation severity. In addition, rotational frequency had the lowest oxidizable C while hay stage stocking treatment had the greatest amount of oxidizable C.

$\underline{\text { Abundance of genes associated with } \mathrm{N}_{2}} \underline{\mathrm{O} \text { production by denitrification }}$

To determine microbial $\mathrm{NO}_{2}^{-}$reduction potential, I quantified the $n i r K$ gene using qPCR. On average, the nirK gene abundance was significantly lower at OF than RV $\left(1.075 \times 10^{5}\right.$ and $2.150 \times 10^{5}$ nirK copies $\mathrm{g}^{-1}$ of dry soil at $\mathrm{OF}$ and $\mathrm{RV}$, respectively; $\mathrm{p}=0.03$ ). At $\mathrm{OF}$, there was no defoliation frequency nor severity effect on nirK gene abundance (Figure 11). However, at RV there was both a moderately significant frequency and severity effect on nirK gene number (Figure 11, frequency and severity effect $\mathrm{p}=0.09$ ), and the frequency $\times$ severity interaction was not significant. At RV, rotational frequency at low severity exhibited the highest nirK abundance, which was on average $58 \%$ greater than all other defoliation treatments. 

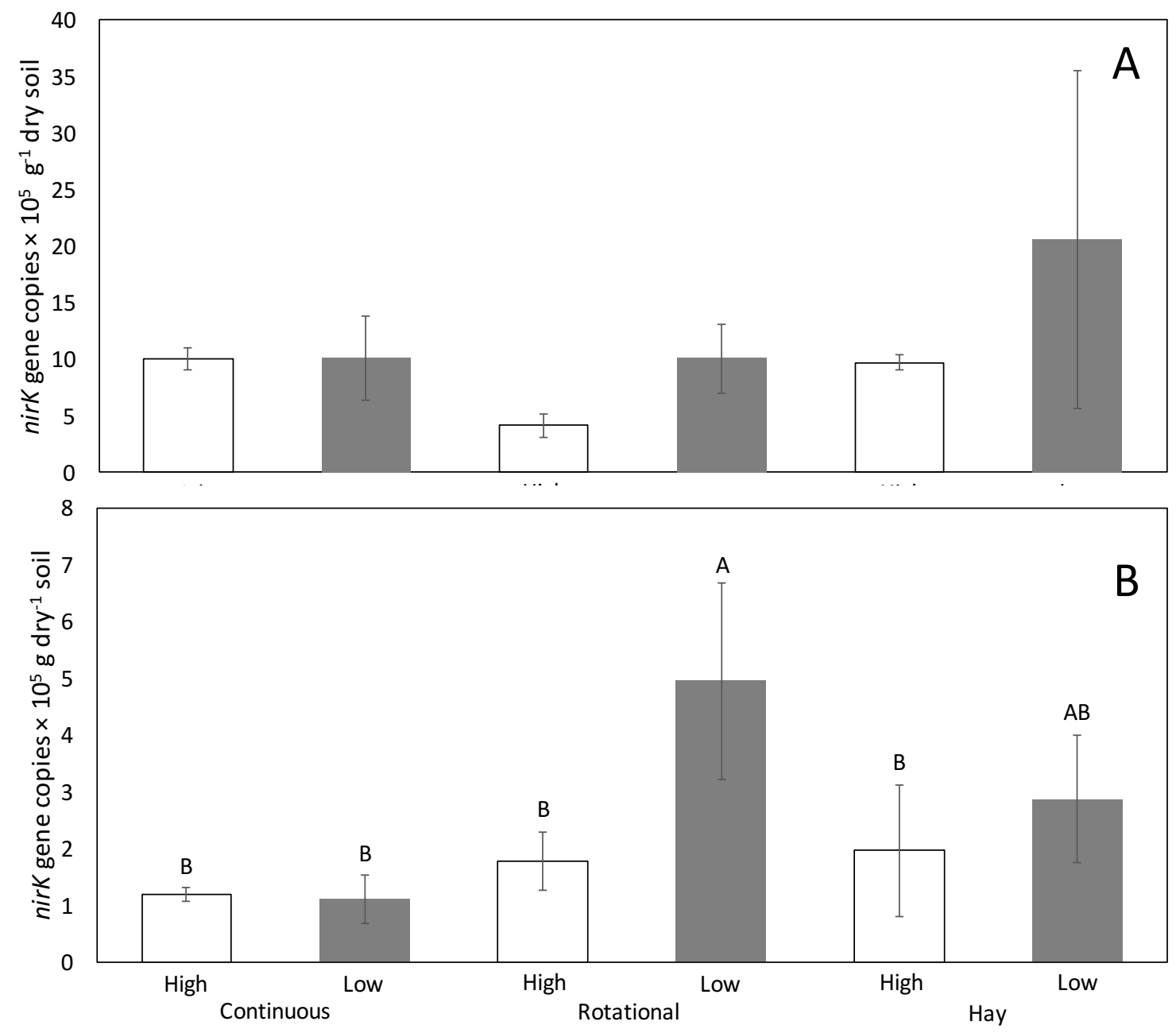

Figure 11: Mean nirK abundance at OF (A) and RV (B) on November 7, 2018. Open bars represent high severity clipping. Solid bars represent low severity clipping. There was no significant main effect or interaction at $\mathrm{OF}$, but at RV both frequency $(p=0.09)$ and severity $(p$ $=0.09$ ) were effect nirK abundance. Letters indicate significant differences between treatment means. All data are presented as means $\pm 1 \mathrm{SE}$.

To determine the impact of defoliation frequency and severity on microbial nitrous oxide reduction potential, I quantified the nos $Z$ gene abundance using qPCR. The mean values for $n o s Z$ gene number were not significantly different between OF and RV, with average values of $3.887 \times 10^{5}$ and $4.147 \times 10^{5} \mathrm{~g}^{-1}$ of dry soil at $\mathrm{OF}$ and $\mathrm{RV}$, respectively. At OF, a marginally significant frequency $\times$ severity interaction was observed (Figure $12, \mathrm{p}=0.09$ ), wherein post-hoc tests revealed that continuously defoliated, high severity treatments exhibited the greatest nos $Z$ 
abundance $(+38 \%$ greater than the mean rotational and hay frequency plots $\mathrm{p}=0.02)$. The continuously defoliated low severity treatments exhibited the lowest nos $Z$ abundance (-38\% lower than the mean rotational and hay plots; $\mathrm{p}=0.07$ ). At $\mathrm{RV}$, plots exposed to continuous frequency exhibited the greatest abundance of nos $Z$, which was $40 \%$ greater than plots that experienced rotational or hay-stage defoliation frequency (Figure 13, frequency effect $\mathrm{p}=0.07$ ). There was no effect of defoliation severity on nos $Z$ abundance at RV.

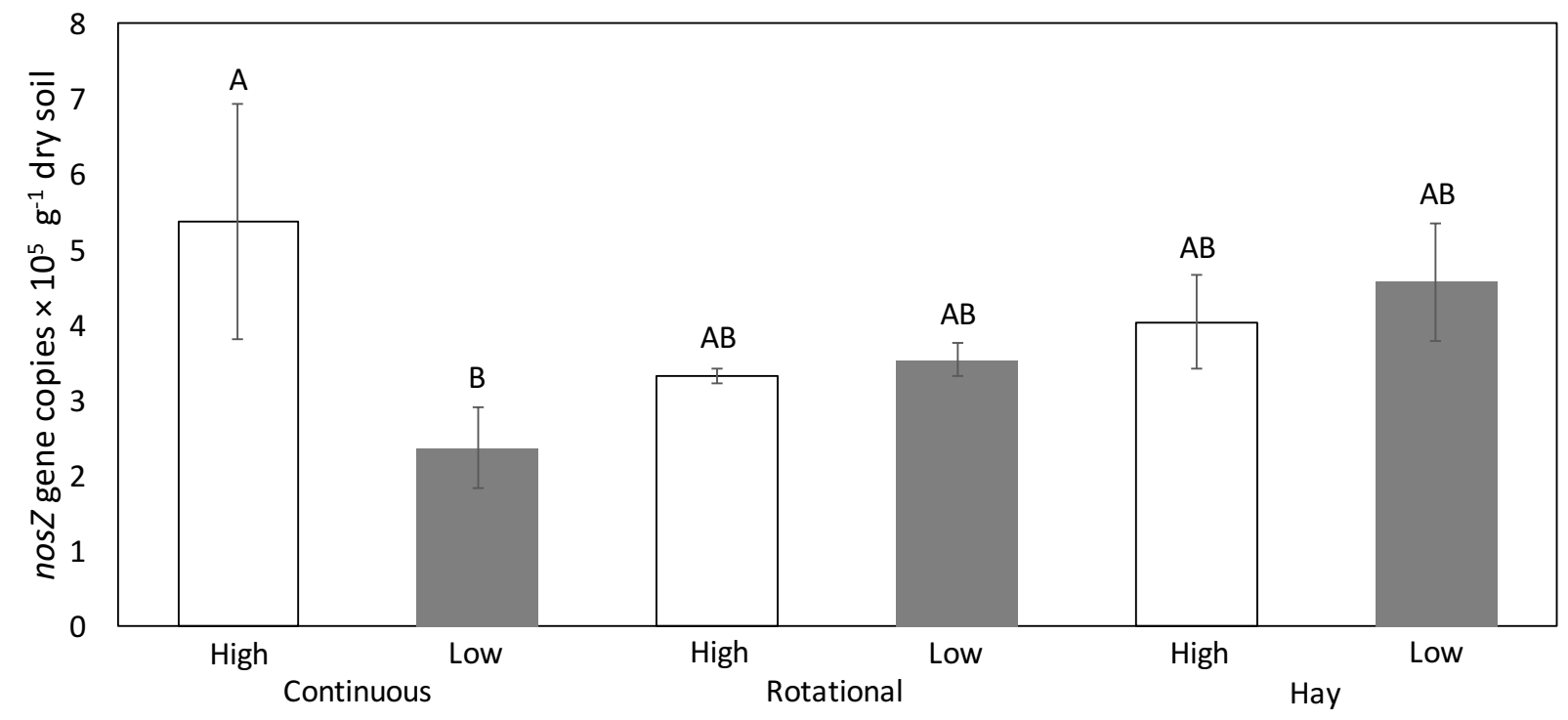

Figure 12: nosZ gene abundance at OF on November 7, 2018. A significant defoliation frequency severity $\times$ interaction was observed. Different letters indicate differences between treatment means using a Student's T-test. All data are presented as means $\pm 1 \mathrm{SE}$. 


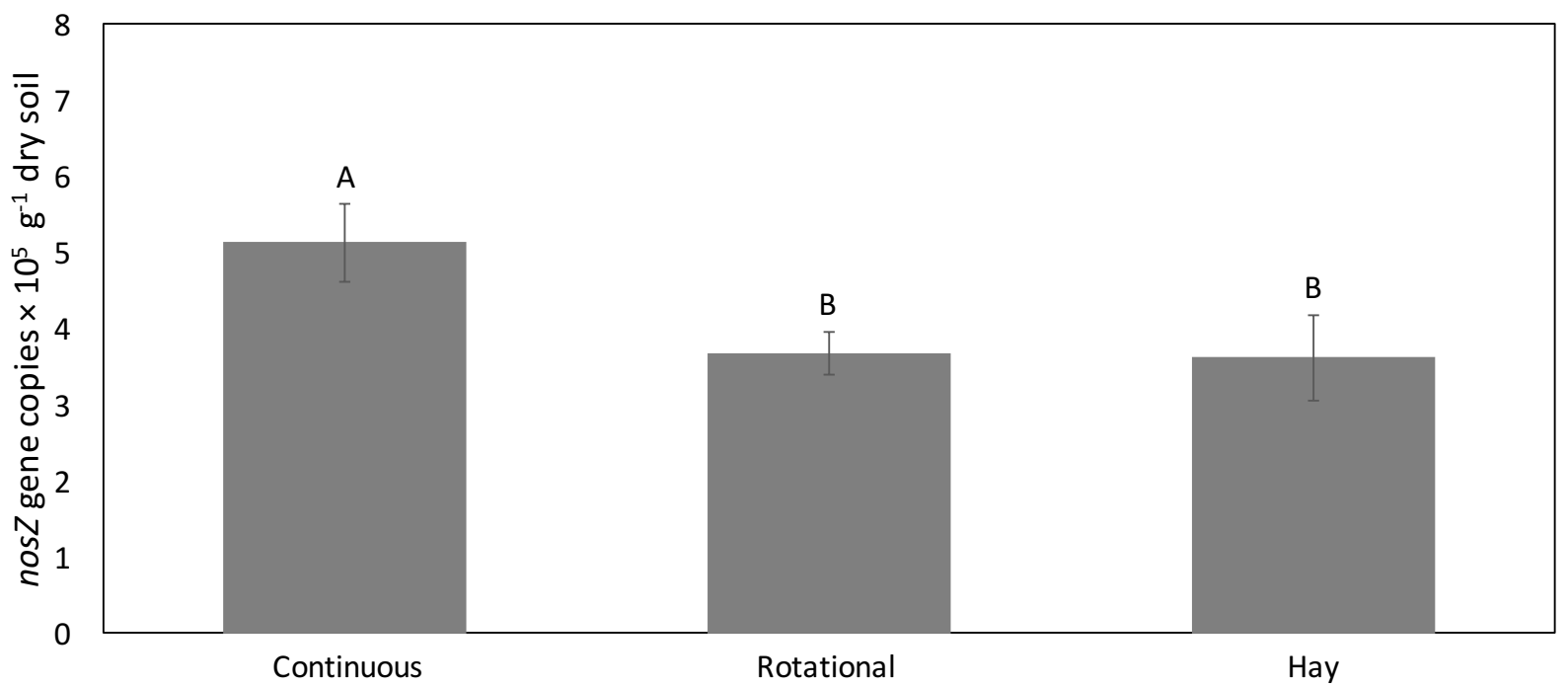

Figure 13: nos $Z$ gene abundance at RV following two years of defoliation treatments. A significant defoliation frequency effect was observed $(\mathrm{p}<0.05)$, but not a severity nor frequency $\times$ severity interaction Different letters indicate differences between treatment means using a Student's T-test. All data are presented as means $\pm 1 \mathrm{SE}$.

To quantify the impact of defoliation treatments on $\mathrm{N}_{2} \mathrm{O}$ emission potential, I calculated the nirK/nosZ ratio (sensu 42, 44) wherein higher values are indicative of a greater potential for $\mathrm{N} 2 \mathrm{O}$ emissions, whereas lower values indicate a lower $\mathrm{N}_{2} \mathrm{O}$ emission potential. The mean values of nirK/nos $Z$ were significantly different by site, whereas abundance equaled 2.807 at $\mathrm{OF}$ and 5.937 at RV ( $p=0.03)$. At OF, a marginally significant severity effect was detected (Figure $14, p$ $=0.09)$, wherein low defoliation severity increased the ratio of nir $/ n o s Z(+45 \%$ increase), which indicates greater $\mathrm{N}_{2} \mathrm{O}$ emissions compared to high defoliation severity. At $\mathrm{RV}$, a marginally significant frequency effect was detected (Figure 15, p =0.08), wherein continuous stocking was only $28 \%$ of the nirK/nos $Z$ ratio of either rotational or hay treatments, indicating a lower $\mathrm{N}_{2} \mathrm{O}$ emission potential. 


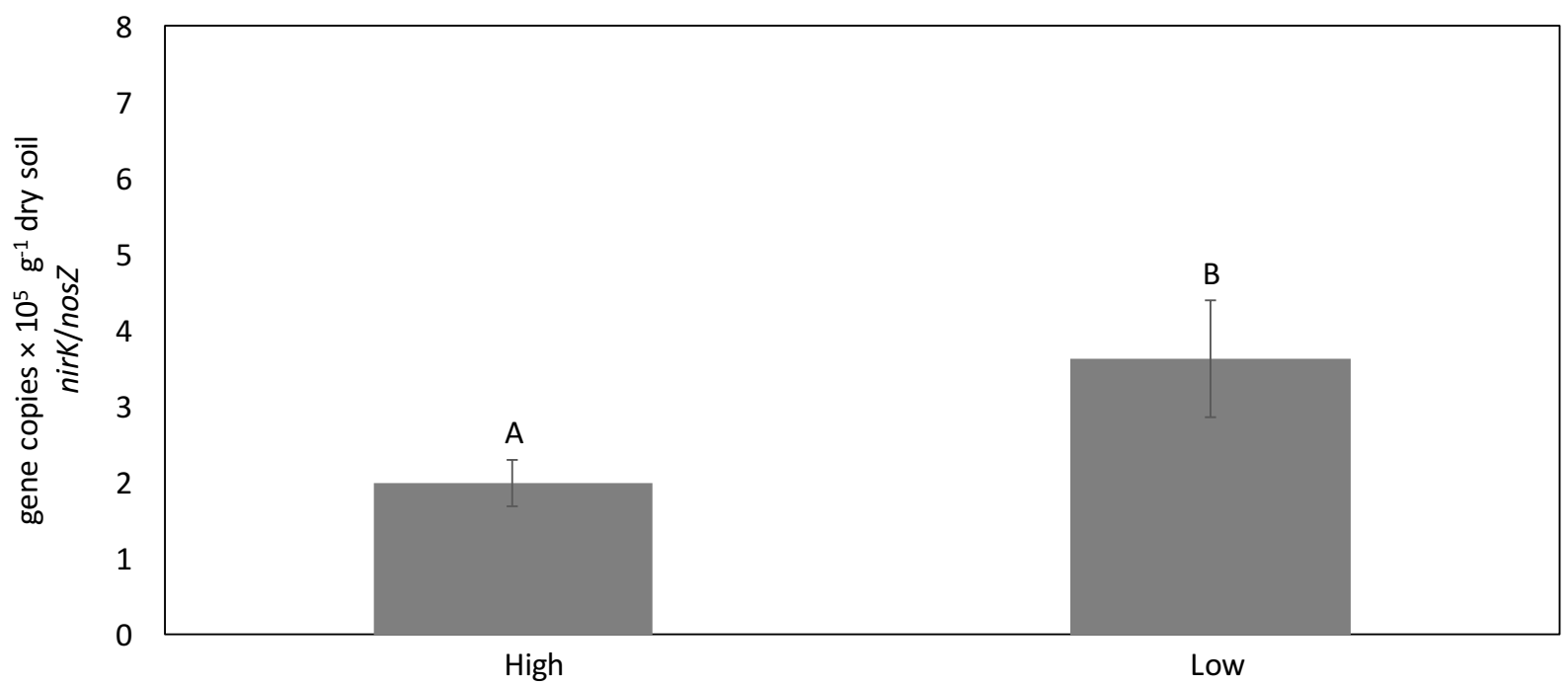

Figure 14: The ratio of gene copies nirK $\mathrm{g}^{-1}$ of dry soil to nos $\mathrm{Z} \mathrm{g}^{-1}$ of dry soil following two years of defoliation treatments at OF. A significant defoliation severity effect was observed ( $\mathrm{p}<$ $0.05)$, but not a frequency nor frequency $\times$ severity interaction All data are presented as means \pm 1SE. Letters separate means $(p<0.05)$

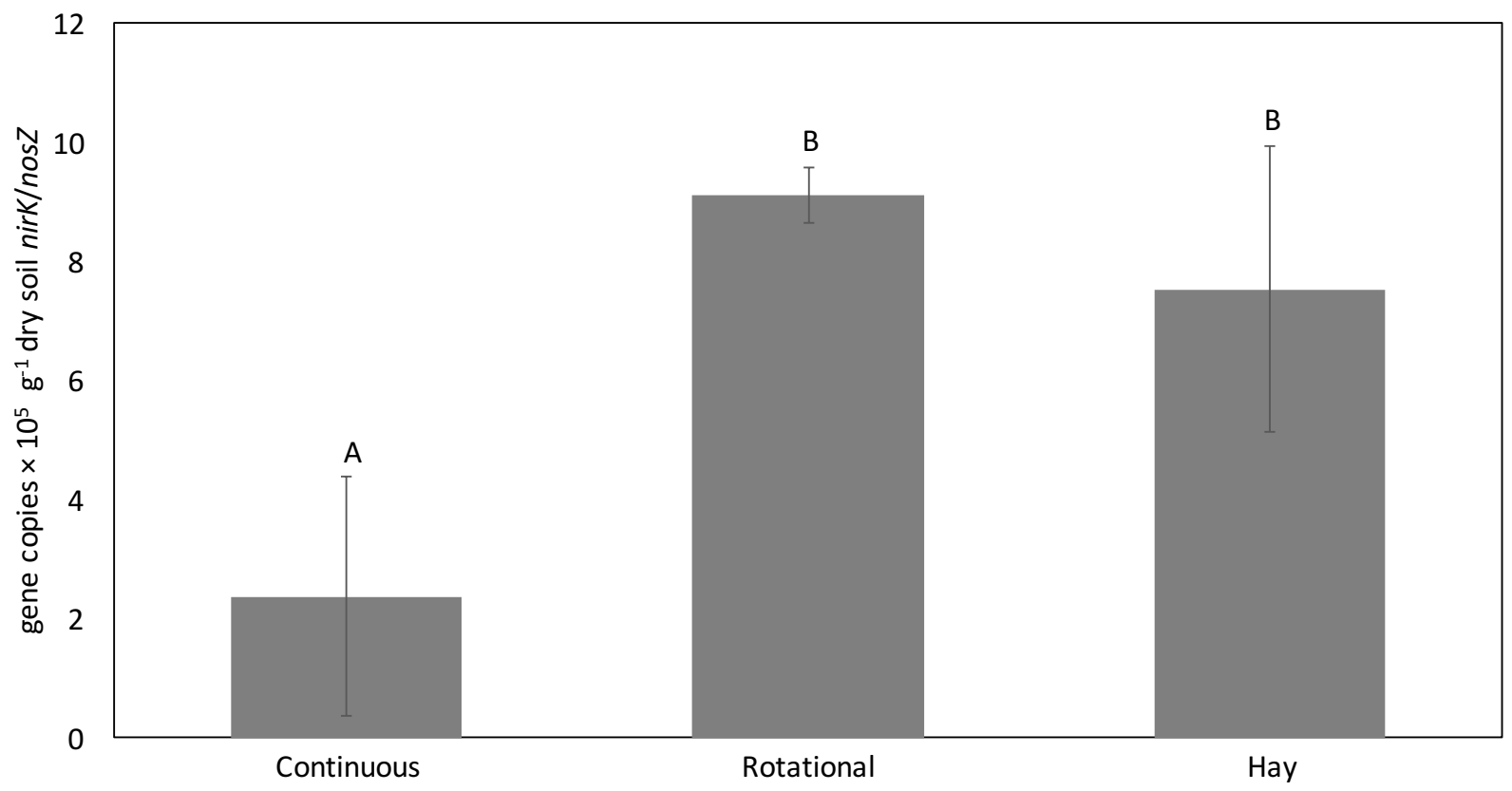

Figure 15: The ratio of nirK g $\mathrm{g}^{-1}$ of dry soil to $\operatorname{nos} \mathrm{Z} \mathrm{g}^{-1}$ of dry soil following two years of defoliation treatments at RV. A significant defoliation frequency effect was observed $(\mathrm{p}<0.05)$, but not a severity or frequency $\times$ severity interaction All data are presented as means $\pm 1 \mathrm{SE}(\mathrm{p}<$ 0.05). Letters indicate significant differences between treatment means. 


\section{Connecting the $\mathrm{C}$ and $\mathrm{N}$ cycle}

To determine the association of soil $\mathrm{C}$ stocks with $\mathrm{N}_{2} \mathrm{O}$ emission potential, I regressed the $\mathrm{C}: \mathrm{N}, \% \mathrm{SOM}$, and $\mathrm{OXC}$ data against nirK/nosZ. C:N was not related to $n i r \mathrm{~K} / n o s \mathrm{Z}$ at either site or when sites were combined. With OF and RV data combined, \% SOM and OXC were significantly, but weakly correlated to the ratio of nirK/nosZ (Figure 16, SOM r ${ }^{2}=0.12, \mathrm{p}=$ 0.04; OXC $\left.\mathrm{r}^{2}=0.13, \mathrm{p}=0.04\right)$. However, when separated by site, at $\mathrm{OF}, \% \mathrm{SOM}$ was significantly associated with the ratio nirK/nosZ (Figure $17, \mathrm{r}^{2}=0.38, \mathrm{p}=0.006$ ), but not OXC $\left(\mathrm{r}^{2}=0.01, \mathrm{p}=0.66\right)$. At RV, \% SOM was not significantly related to the ratio of nirK/nosZ $\left(\mathrm{r}^{2}=\right.$ $0.02, \mathrm{p}=0.54)$, nor was $\mathrm{OXC}\left(\mathrm{r}^{2}=0.07, \mathrm{p}=0.30\right)$. 

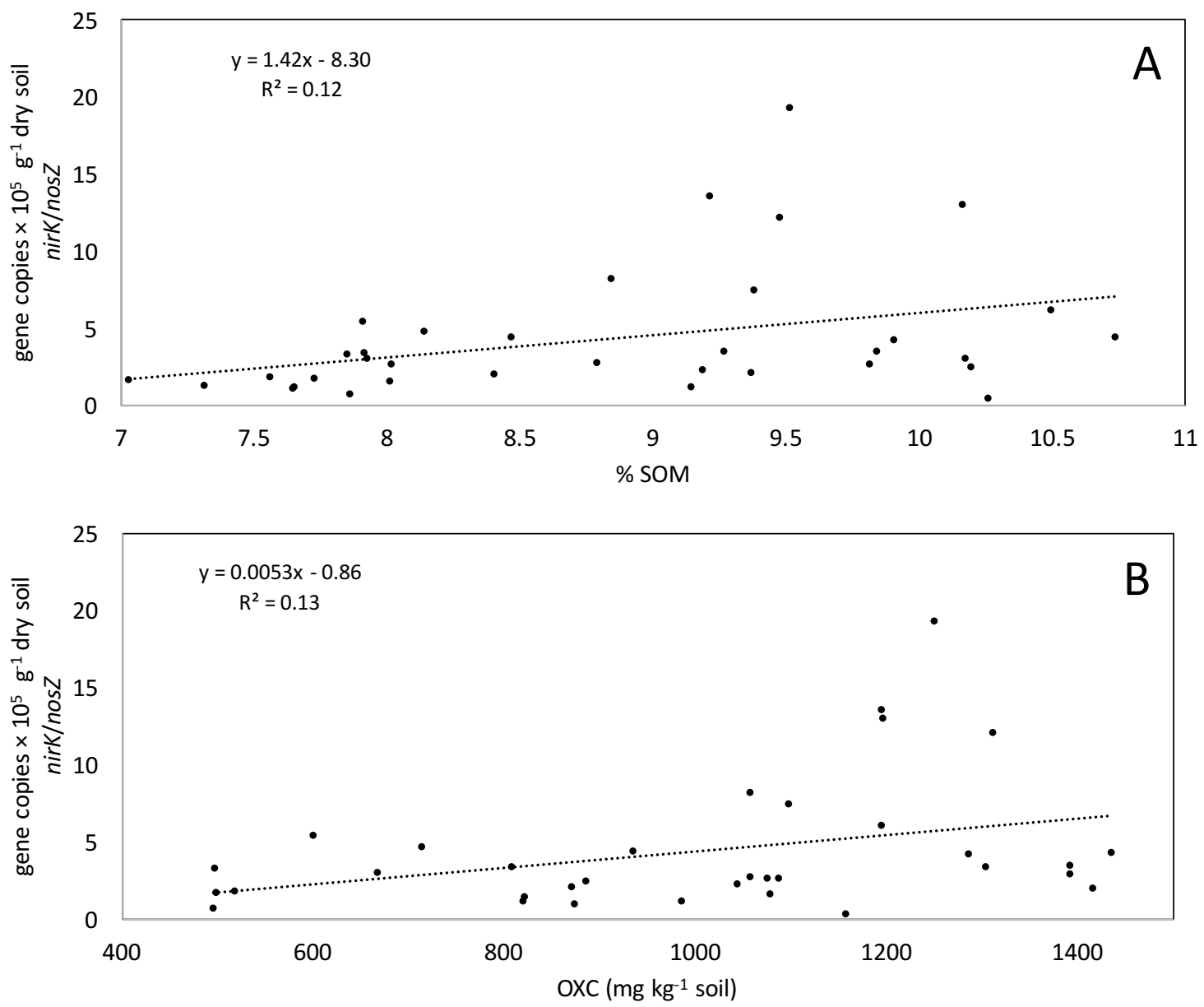

Figure 16: Linear regression relating the ratio nirK/nos $Z$ to $\% \mathrm{SOM}(\mathrm{A})$ and $\mathrm{OXC}(\mathrm{B})$ including both $\mathrm{OF}$ and $\mathrm{RV}$ data $(\mathrm{A}, \mathrm{p}=0.04)$. Linear regression relating $\mathrm{OXC}$ to the ratio $n i r K / n o s Z$ including both OF and RV data $(\mathrm{B}, \mathrm{p}=0.04)$. 


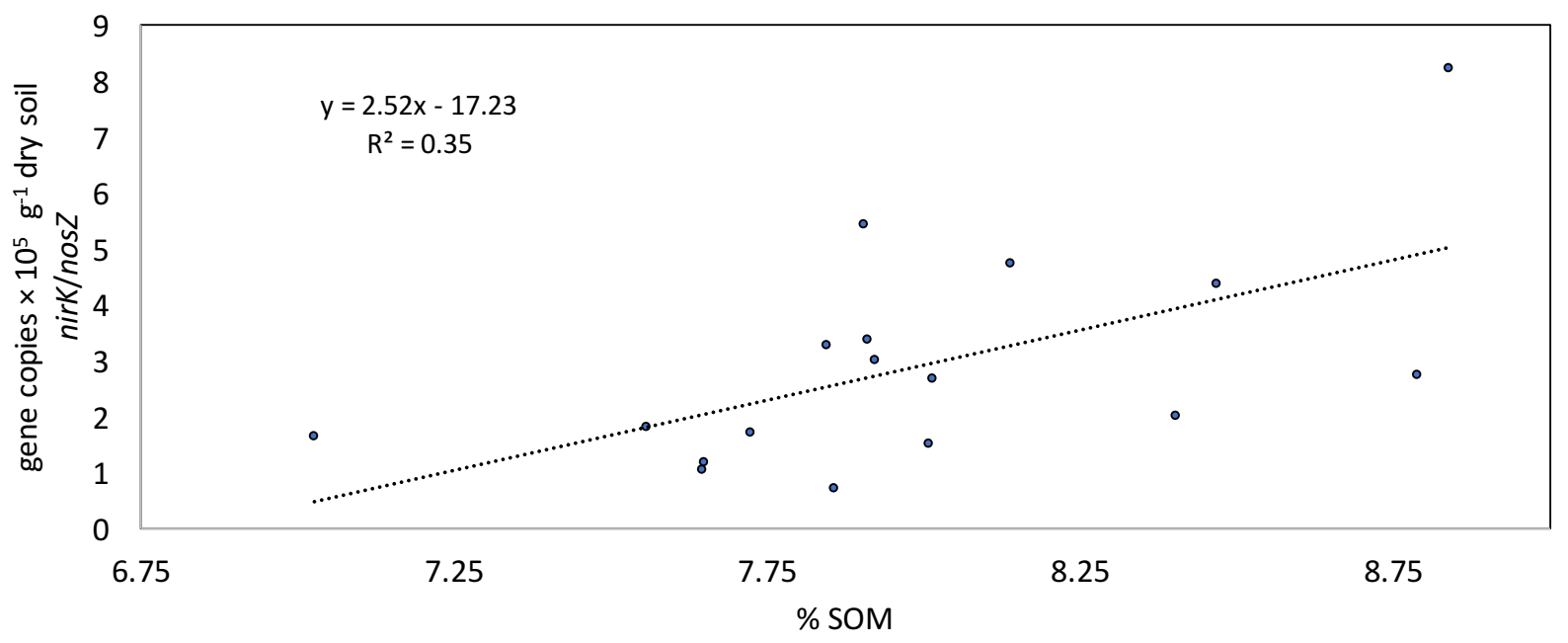

Figure 17: Linear regression relating $\% \mathrm{SOM}$ to the ratio nirK/nos $Z$ at $\mathrm{OF}(\mathrm{p}=0.006)$.

\section{Discussion}

In this study, I determined that greater defoliation severity decreased $\mathrm{N}_{2} \mathrm{O}$ emission potential via reduced SOM and oxidizable C availability in two West Virginia managed pastures. Further, the association between $\mathrm{N}_{2} \mathrm{O}$ emission potential and soil $\mathrm{C}$ stock (i.e, $\mathrm{SOM}$ ) was greatest at $\mathrm{OF}$, not at RV. Across all experimental plots in both OF and RV, SOM $\left(\mathrm{r}^{2}=0.12, \mathrm{p}=0.04\right)$ and oxidizable $\mathrm{C}$ was associated $\left(\mathrm{r}^{2}=0.13, \mathrm{p}=0.04\right)$ with greater $\mathrm{N}_{2} \mathrm{O}$ emission potential, however both associations were weak. This suggests that while common environmental parameters may influence $\mathrm{N}_{2} \mathrm{O}$ emissions across sites, the same environmental may constrain $\mathrm{N}_{2} \mathrm{O}$ emissions differently under different soil physico-chemical conditions. Further, it is plausible that other unmeasured soil physiochemical factors may be impacting $\mathrm{N}_{2} \mathrm{O}$ emission potential in this experiment. There are four major requirements for denitrification to occur: the presence of denitrifying bacteria, the availability of organic $\mathrm{C}, \mathrm{O}_{2}$ restriction, and presence of Noxides $(92,95)$. In addition, the denitrifying community may be shaped by a variety of distal controls including: $\mathrm{C}$ availability, $\mathrm{pH}$, and soil moisture. Further, soil moisture and soil $\mathrm{pH}$ are 
major determinants of microbial abundance and diversity (116). In this study, soil $\mathrm{pH}$ and soil moisture did not differ across defoliation management treatments for the sampling period, thus, observed changes in $\mathrm{N}_{2} \mathrm{O}$ emission potential are most likely linked to defoliation-induced changes in soil $\mathrm{C}$ stocks. However, the availability of nitrate $\left(\mathrm{NO}_{3}{ }^{-}\right)$, the substrate in the first reaction in denitrification, can influence $\mathrm{N}_{2} \mathrm{O}$ emissions $((92,95))$, further study should include assessments of soil $\mathrm{NO}_{3}$ in relation to $\mathrm{N}_{2} \mathrm{O}$ emissions. These results support my hypothesis that the soil microbial potential for $\mathrm{N}_{2} \mathrm{O}$ emissions will be increased with increasing availability of soil $\mathrm{C}$, attributable to indirect effects caused by defoliation management strategy $(8,20,35,92$, 117).

Data generated in this study begin to illuminate a possible mechanism by which defoliation intensity and severity may increase the nirK:nos $Z$ ratio, and hence the $\mathrm{N}_{2} \mathrm{O}$ emission potential of soils through changes in both above- and below-ground dynamics. Firstly, defoliation can alter belowground $\mathrm{C}$ dynamics via changes in plant physiology, namely, $\mathrm{C}$ allocation to root tissues and exudation of low molecular weight $\mathrm{C}$ compounds from roots at less frequent defoliation events $(8,39,118)$. Secondly, variations in defoliation management may enhance or reduce $\mathrm{C}$ allocation to roots, which supply the microbial community with important $\mathrm{C}$ substrate fueling metabolism (119). In addition, grazing tolerant plants have a greater ability to allocate $\mathrm{C}$ to roots following defoliation events (120). As a result, if $\mathrm{N}_{2} \mathrm{O}$ emissions are constrained by labile $\mathrm{C}$ availability, grazing-tolerant plants would harbor microbial communities with increased $\mathrm{N}_{2} \mathrm{O}$ emission potential due to the plant's greater capacity to supply soil microbial communities with $\mathrm{C}$. However, grazing-tolerant plants can also reduce $\mathrm{N}_{2} \mathrm{O}$ emissions in situ (121), thus further investigations are needed to resolve plant-soil feedbacks between grazing tolerant plant and microbial functional guilds associated with $\mathrm{N}_{2} \mathrm{O}$ emissions. 
In this study, I quantified the genes responsible for $\mathrm{N}_{2} \mathrm{O}$ production and reduction by denitrification; further study should also include $\mathrm{N}_{2} \mathrm{O}$ emission potential by nitrification. In defoliated grasslands, a nitrification inhibitor reduced $\mathrm{NO}_{2}{ }^{-}$and consequently $\mathrm{N}_{2} \mathrm{O}$ emissions by $57 \%$ (122). In future studies, it is important to consider nitrification-based $\mathrm{N}_{2} \mathrm{O}$ emission because it is plausible that soil parameters associated with increased denitrification-based $\mathrm{N}_{2} \mathrm{O}$ emission may also be associated with decreased nitrification-based $\mathrm{N}_{2} \mathrm{O}$ emissions and viceversa $(123,124)$. For example, if the abundance of nitrifying bacteria is decreased, but the abundance of nitrite reducers remains the same nitrite/nitrate concentrations could be reduced, as well as, $\mathrm{N}_{2} \mathrm{O}$ emissions. For example, $\mathrm{N}$ fertilization can increase the abundance of nitrifying and denitrifying bacteria with no change in the diversity of nitrifying communities (125). In future studies, including assessments of nitrification-based $\mathrm{N}_{2} \mathrm{O}$ emissions would provide important information for more accurately assessing $\mathrm{N}_{2} \mathrm{O}$ emission potential across defoliation management strategies.

To successfully implement progressive defoliation management strategies, plant productivity must be satisfactory to the land owner. In this study, the treatment exhibiting the lowest potential for $\mathrm{N}_{2} \mathrm{O}$ emissions also exhibited the lowest utilization at $\mathrm{OF}$, which could prevent it from being implemented by land managers. This pattern was repeated at RV where continuous defoliation resulted in both the lowest $\mathrm{N}_{2} \mathrm{O}$ emission potential and lowest utilization. Selection of low-GHG associated plant species may help improve the environmental sustainability of increased productivity, as highly-productive plant mixtures had the lowest $\mathrm{N}_{2} \mathrm{O}$ emissions in a recent mesocosm study (121). Also, C additions to pastures decreased $\mathrm{N}_{2} \mathrm{O}$ emissions through adsorption of urine-derived ammonia without sacrificing productivity (126). Although the data presented here do not indicate $\mathrm{N}_{2} \mathrm{O}$ emissions can be limited while providing 
comparable productivity rates, other studies have shown promising results. Further study into environmentally sustainable management strategies will help to together optimize land productivity with the minimization of harmful GHG emissions.

Currently, organic agricultural management is being utilized to improve above-and below-ground biodiversity and increase soil $\mathrm{C}(70,127)$. For example, a recent meta-analysis found that organically managed farms exhibited greater soil C storage compared to conventionally managed farms (70). However, given what I and others $(20,92,95)$ have shown, increased soil $\mathrm{C}$ can lead to greater increases in $\mathrm{N}_{2} \mathrm{O}$ emission potential in organically managed pasture than conventionally managed pasture. However, in this study, $\mathrm{N}_{2} \mathrm{O}$ emission potential was overall greater in conventionally managed pastures as compared to organically managed pasture, but it did not respond to any defoliation treatment. This finding contrasts other research indicating greater $\mathrm{N}_{2} \mathrm{O}$ emissions from organic standards (107), and is possibly due to a $24 \%$ greater SOM content at the RV farm (i.e., conventionally managed) versus the OF (i.e., organically managed). In this study, $\mathrm{OF} \mathrm{N}_{2} \mathrm{O}$ emission potential was more closely associated with soil C stocks (Fig 11) than RV soils. Thus, organically managed pasture lands may be more amenable to defoliation management than conventional management, regarding soil C and GHG emissions. In future studies, differences in organic farming and conventional farming responses to management and environmental changes should be properly investigated to understand how the different land management strategies impact GHG emissions.

Future research should include not only impacts of pasture defoliation, but also other selective pressures associated with livestock grazing, e.g., excreta and soil compaction, to better understand the impact pasture grazing has on the capacity for soil microbes to produce $\mathrm{N}_{2} \mathrm{O}$. For example, livestock excreta produce hot spots of high nutrients, which could increase microbial 
activity and increase the availability of $\mathrm{N}$ for nitrification and denitrification, which may ultimately result in greater $\mathrm{N}_{2} \mathrm{O}$ emission (128). In addition, soil compaction from cattle grazing increases the amount of soil under anoxic conditions, thus increasing denitrification rates and $\mathrm{N}_{2} \mathrm{O}$ production (129). Future studies should also examine temporal changes across growing season and years, as $\mathrm{N}_{2} \mathrm{O}$ emissions can vary dramatically over time $(130,131)$.

\section{Conclusion}

Overall, these results suggest a mechanism for the microbial response to defoliation management through the increased availability of soil $\mathrm{C}$, as two years of differential defoliation management strategies produced changes in the $\mathrm{N}_{2} \mathrm{O}$ emission potential of $\mathrm{C}_{3}$ pastures via differences in SOM and labile C. In addition, organically managed pasture had the least $\mathrm{N}_{2} \mathrm{O}$ emission potential when managed in a rotational fashion, while conventional management had the least $\mathrm{N}_{2} \mathrm{O}$ emission potential when continuously defoliation. To limit $\mathrm{N}_{2} \mathrm{O}$ emissions from organically managed WV pastures, defoliation should occur at moderate (i.e., 28-35 day) intervals at a high severity (i.e., height of $6 \mathrm{~cm}$ ), however defoliation at frequent (i.e., 7-10 day intervals) and a low severity (i.e., height of either 8 or $12 \mathrm{~cm}$ ) would be appropriate in conventionally managed pastures. Overall, these findings improve understanding of how changes in environmental parameters associated with pasture land management may alter the $\mathrm{N}_{2} \mathrm{O}$ emission potential in pasture soils and will aid in developing best management practices (BMPs) to minimize $\mathrm{N}_{2} \mathrm{O}$ emissions from pasture land. 


\section{Works Cited}

1. Sinsabaugh RL, Hill BH, Follstad Shah JJ. 2009. Ecoenzymatic stoichiometry of microbial organic nutrient acquisition in soil and sediment. Nature 462:795-798.

2. Allison SD, Vitousek PM. 2005. Responses of extracellular enzymes to simple and complex nutrient inputs. Soil Biol Biochem 37:937-944.

3. Liang B, Lehmann J, Solomon D, Kinyangi J, Grossman J, O’Neill B, Skjemstad JO, Thies J, Luizão FJ, Petersen J, Neves EG. 2006. Black carbon increases cation exchange capacity in soils. Soil Sci Soc Am J 70:1719.

4. Schmidt MWI, Torn MS, Abiven S, Dittmar T, Guggenberger G, Janssens IA, Kleber M, Kögel-Knabner I, Lehmann J, Manning DAC, Nannipieri P, Rasse DP, Weiner S, Trumbore SE. 2011. Persistence of soil organic matter as an ecosystem property. Nature 478:49-56.

5. Lal R. 2006. Enhancing crop yields in the developing countries through restoration of the soil organic carbon pool in agricultural lands. L Degrad Dev 17:197-209.

6. Schlesinger WH, Bernhardt ES. 2013. Biogeochemistry, 3rd ed. Elsevier, San Diego.

7. Lal R. 2018. Digging deeper: A holistic perspective of factors affecting soil organic carbon sequestration in agroecosystems. Glob Chang Biol. 24: 3285-3301.

8. Wilson CH, Strickland MS, Hutchings JA, Bianchi TS, Flory SL. 2018. Grazing enhances belowground carbon allocation, microbial biomass, and soil carbon in a subtropical grassland. Glob Chang Biol. 24: 2997-3009 .

9. USDA. 2006. Land resource regions and major land resource areas of the United States, the Caribbean,and the Pacific basin. United States Dep Agric Handb 296.

10. Borer ET, Seabloom EW, Gruner DS, Harpole WS, Hillebrand H, Lind EM, Yang LH. 2014. Herbivores and nutrients control grassland plant diversity via light limitation. Nature 508:1-20.

11. Maron JL, Jefferies RL. 2001. Restoring enriched grasslands: Effects of mowing on species richness, productivity, and nitrogen retention. Ecol Appl 11:1088-1100.

12. Oesterheld M, McNaughton SJ. 1991. Effect of stress and time for recovery on the amount of compensatory growth after grazing. Oecologia 85:305-313.

13. Collins SL, Knapp AK, Briggs JM, Blair JM, Steinauer EM. 1998. Modulation of diversity by grazing and mowing in native tallgrass prairie. Science (80- ) 280:745-747.

14. Augustine DJ, McNaughton SJ. 1998. Ungulate effects on the functional species composition of plant communities: herbivore selectivity and plant tolerance. J Wildl Manage 62:1165.

15. Frank DA, Kuns MM, Guido DR. 2011. Consumer control of grassland plant production. Source Ecol Ecol 83:602-606.

16. Patra AK, Abbadie L, Clays-Josserand A, Degrange V, Grayston SJ, Guillaumaud N, Loiseau P, Louault F, Mahmood S, Nazaret S, Philippot L, Poly F, Prosser JI, 
Roux X Le. 2006. Effects of management regime and plant species on the enzyme activity and genetic structure of $\mathrm{N}$-fixing, denitrifying and nitrifying bacterial communities in grassland soils. Environ Microbiol 8:1005-1016.

17. Vaieretti MV, Cingolani AM, Pérez Harguindeguy N, Cabido M. 2013. Effects of differential grazing on decomposition rate and nitrogen availability in a productive mountain grassland. Plant Soil 371:675-691.

18. Crowther TW, Thomas SM, Maynard DS, Baldrian P, Covey K, Frey SD, van Diepen LTA, Bradford MA. 2015. Biotic interactions mediate soil microbial feedbacks to climate change. Proc Natl Acad Sci 112:7033-7038.

19. A'Bear AD, Johnson SN, Jones TH. 2014. Putting the "upstairs-downstairs" into ecosystem service: What can aboveground-belowground ecology tell us? Biol Control 75:97-107.

20. Henry S, Texier S, Hallet S, Bru D, Dambreville C, Chèneby D, Bizouard F, Germon JC, Philippot L. 2008. Disentangling the rhizosphere effect on nitrate reducers and denitrifiers: Insight into the role of root exudates. Environ Microbiol 10:3082-3092.

21. Mawdsley JL, Bardgett RD. 1997. Continuous defoliation of perennial ryegrass (Lolium perenne) and white clover (Trifolium repens) and associated changes in the composition and activity of the microbial population of an upland grassland soil. Biol Fertil Soils 24:52-58.

22. Mikola J, Yeates GW, Barker GM, Wardle DA, Bonner KI. 2001. Effects of defoliation intensity on soil food-web properties in an experimental grassland community. Oikos 92:333-343.

23. Gao YZ, Giese M, Lin S, Sattelmacher B, Zhao Y, Brueck H. 2008. Belowground net primary productivity and biomass allocation of a grassland in Inner Mongolia is affected by grazing intensity. Plant Soil 307:41-50.

24. Prieto LH, Bertiller MB, Carrera AL, Olivera NL. 2011. Soil enzyme and microbial activities in a grazing ecosystem of Patagonian Monte, Argentina. Geoderma 162:281287.

25. Tiedemann A, Klemmedson J. 1973. Effect of Mesquite on physical and chemical properties of the soil. J Range Manag 26:27-29.

26. Barbehenn R V., Chen Z, Karowe DN, Spickard A. 2004. C3 grasses have higher nutritional quality than $\mathrm{C} 4$ grasses under ambient and elevated atmospheric $\mathrm{CO} 2$. Glob Chang Biol 10:1565-1575.

27. Chen W, Huang D, Liu N, Zhang Y, Badgery WB, Wang X, Shen Y. 2015. Improved grazing management may increase soil carbon sequestration in temperate steppe. Sci Rep 5:10892.

28. Cornwell WK, Cornelissen JHC, Amatangelo K, Dorrepaal E, Eviner VT, Godoy O, Hobbie SE, Hoorens B, Kurokawa H, Pérez-Harguindeguy N, Quested HM, Santiago LS, Wardle DA, Wright IJ, Aerts R, Allison SD, Van Bodegom P, Brovkin V, Chatain A, Callaghan T V., Díaz S, Garnier E, Gurvich DE, Kazakou E, Klein JA, 
Read J, Reich PB, Soudzilovskaia NA, Vaieretti MV, Westoby M. 2008. Plant species traits are the predominant control on litter decomposition rates within biomes worldwide. Ecol Lett 11:1065-1071.

29. Ross DJ, Tate KR, Newton PCD, Clark H. 2002. Decomposability of C3 and C4 grass litter sampled under different concentrations of atmospheric carbon dioxide at a natural $\mathrm{CO}_{2}$ spring. Plant Soil 240:275-286.

30. Bardgett RD, Wardle DA. 2003. Herbivore-mediated linkages between aboveground and belowground communities. Ecology 84:2258-2268.

31. McNaughton SJ. 1983. Compensatory plant growth as a response to herbivory. Oikos 40:329.

32. Menaughton SJ. 1985. Effects of phosphorus nutrition and defoliation on C4 graminoids from the Serengeti plains. Ecology 66:1617-1629.

33. Hobbs NT. 1996. Modification of ecosystems by ungulates. J Wildl Manage 60:695.

34. Ruess RW, McNaughton SJ. 1987. Grazing and the dynamics of nutrient and energy regulated microbial processes in the Serengeti grasslands. Oikos 49:101.

35. Peschel AR, Zak DR, Cline LC, Freedman Z. 2015. Elk, sagebrush, and saprotrophs: Indirect top-down control on microbial community composition and function. Ecology 96:2383-2393.

36. Crider FJ. 1955. Root-growth stoppage resulting from defoliation of grassTechnical Bulletin 1102. Washington D.C.

37. Chaparro JM, Badri D V., Vivanco JM. 2014. Rhizosphere microbiome assemblage is affected by plant development. ISME J 8:790-803.

38. Eilers KG, Lauber CL, Knight R, Fierer N. 2010. Shifts in bacterial community structure associated with inputs of low molecular weight carbon compounds to soil. Soil Biol Biochem 42:896-903.

39. Hamilton EW, Frank DA. 2001. Can plants stimulate soil microbes and their own Nutrient supply? Evidence from agrazing tolerant grass. Ecology 82:2397-2402.

40. Allison SD, Wallenstein MD, Bradford MA. 2010. Soil-carbon response to warming dependent on microbial physiology. Nat Geosci 3:336-340.

41. Schimel JP, Schaeffer SM. 2012. Microbial control over carbon cycling in soil. Front Microbiol 3:348.

42. Manzoni S, Taylor P, Richter A, Porporato A, Ågren GI. 2012. Environmental and stoichiometric controls on microbial carbon-use efficiency in soils. New Phytol 196:7991.

43. Cotrufo MF, Wallenstein MD, Boot CM, Denef K, Paul E. 2013. The Microbial Efficiency-Matrix Stabilization (MEMS) framework integrates plant litter decomposition with soil organic matter stabilization: Do labile plant inputs form stable soil organic matter? Glob Chang Biol 19:988-995. 
44. Cotrufo MF, Soong JL, Horton AJ, Campbell EE, Haddix ML, Wall DH, Parton WJ. 2015. Formation of soil organic matter via biochemical and physical pathways of litter mass loss. Nat Geosci 8:776-779.

45. Kallenbach CM, Frey SD, Grandy AS. 2016. Direct evidence for microbial-derived soil organic matter formation and its ecophysiological controls. Nat Commun 7:13630.

46. Sinsabaugh RL, Lauber CL, Weintraub MN, Ahmed B, Allison SD, Crenshaw C, Contosta AR, Cusack D, Frey S, Gallo ME, Gartner TB, Hobbie SE, Holland K, Keeler BL, Powers JS, Stursova M, Takacs-Vesbach C, Waldrop MP, Wallenstein MD, Zak DR, Zeglin LH. 2008. Stoichiometry of soil enzyme activity at global scale. Ecol Lett 11:1252-1264.

47. Sinsabaugh RL, Moorhead DL. 1994. Resource allocation to extracellular enzyme production: A model for nitrogen and phosphorus control of litter decomposition. Soil Biol Biochem 26:1305-1311.

48. Patra AK, Abbadie L, Clays-Josserand A, Degrange V, Grayston SJ, Loiseau P, Louault F, Mahmood S, Nazaret S, Philippot L, Poly F, Prosser JI, Richaume A, Le Roux X. 2005. Effects of grazing on microbial functional groups involved in soil N dynamics. Ecol Monogr 75:65-80.

49. Holt J. 1997. Grazing pressure and soil carbon, microbial biomass and enzyme activities in semi-arid northeaster Australia. Appl soil Ecol 5:143-149.

50. USDA, NRCS. 2013. Natural Resource Conservation Service Conservation Programs. Morgantown, WV.

51. 2017. Datasets | Climate Data Online (CDO) | National Climatic Data Center (NCDC). NOAA.

52. Sanderson MA, Rotz CA, Fultz SW, Rayburn EB. 2001. Estimating forage mass with a commercial capacitance meter, rising plate meter, and pasture ruler. Agron J 93:12811286.

53. Rousk J, Bååth E, Brookes PC, Lauber CL, Lozupone C, Caporaso JG, Knight R, Fierer N. 2010. Soil bacterial and fungal communities across a $\mathrm{pH}$ gradient in an arable soil. ISME J 4:1340-1351.

54. Rayment G, Higginson F. 1992. Soil Survey Standard Test Method pH: 1:5 Soil:0.01M $\mathrm{CaCl} 2$ Suspension. Aust Lab Handb Soil Water Chem Methods 3:5-7.

55. Culman SW, Snapp SS, Ollenburger M, Basso B, DeHaan LR. 2013. Soil and water quality rapidly responds to the perennial grain Kernza wheatgrass. Agron J 105:735-744.

56. Sinsabaugh RL, Lauber CL, Weintraub MN, Ahmed B, Allison SD, Crenshaw C, Contosta AR, Cusack D, Frey S, Gallo ME, Gartner TB, Hobbie SE, Holland K, Keeler BL, Powers JS, Stursova M, Takacs-Vesbach C, Waldrop MP, Wallenstein MD, Zak DR, Zeglin LH. 2008. Stoichiometry of soil enzyme activity at global scale. Ecol Lett 11:1252-1264.

57. Saiya-Cork KR, Sinsabaugh RL, Zak DR. 2002. The effects of long term nitrogen 
deposition on extracellular enzyme activity in an Acer saccharum forest soil. Soil Biol Biochem 34:1309-1315.

58. Matulich KL, Weihe C, Allison SD, Amend AS, Berlemont R, Goulden ML, Kimball S, Martiny AC, Martiny JBH. 2015. Temporal variation overshadows the response of leaf litter microbial communities to simulated global change. ISME J 9:2477-2489.

59. Marti J A. 2001. A new method for non-parametric multivariate analysis of variance. Austral Ecol 26:32-46.

60. Legendre P, Legendre L. 1998. Numerical Ecology. Second English Edition. Dev Environ Model 20.

61. Oksanen J, Blanchet F, Kindt R, Legendre P, Minchin PR, O'Hara RB, Simpson GL, Solymos P, Stevens MHH, Wagner H. 2016. Vegan: Community Ecology Package. R packag. 2.3-3.

62. R. 2017. R: A Language and Environment for Statistical Computing.

63. Hamilton EW, Frank DA. 2001. Can plants stimulate soil microbes and their own nutrient supply? Evidence from a grazing tolerant grass. Ecology 82:2397-2402.

64. Ingram LJ, Stahl PD, Schuman GE, Buyer JS, Vance GF, Ganjegunte GK, Welker JM, Derner JD. 2008. Grazing Impacts on Soil Carbon and Microbial Communities in a Mixed-Grass Ecosystem. Soil Sci Soc Am J 72:939.

65. Acosta-Martínez V, Bell CW, Morris BEL, Zak J, Allen VG. 2010. Long-term soil microbial community and enzyme activity responses to an integrated cropping-livestock system in a semi-arid region. Agric Ecosyst Environ 137:231-240.

66. Hamilton EW, Frank DA, Hinchey PM, Murray TR. 2008. Defoliation induces root exudation and triggers positive rhizospheric feedbacks in a temperate grassland. Soil Biol Biochem 40:2865-2873.

67. Augustine DJ, Dijkstra FA, Hamilton EW, Morgan JA. 2011. Rhizosphere interactions, carbon allocation, and nitrogen acquisition of two perennial North American grasses in response to defoliation and elevated atmospheric CO2. Oecologia 165:755-770.

68. Ziter C, Macdougall AS. 2013. Nutrients and defoliation increase soil carbon inputs in grassland. Ecology 94:106-116.

69. Meier IC, Finzi AC, Phillips RP. 2017. Root exudates increase N availability by stimulating microbial turnover of fast-cycling N pools. Soil Biol Biochem 106:119-128.

70. Gattinger A, Muller A, Haeni M, Skinner C, Fliessbach A, Buchmann N, Mader P, Stolze M, Smith P, Scialabba NE-H, Niggli U. 2012. Enhanced top soil carbon stocks under organic farming. Proc Natl Acad Sci 109:18226-18231.

71. Marriot EE, Wander MM. 2006. Total and labile soil organic matter in organic and conventional farming systems. Soil Sci Soc Am J 70:950-959.

72. Mondelaers K, Aertsens J, van Huylenbroeck G. 2009. A meta-analysis of the differences in environmental impacts between organic and conventional farming. Br Food 
J 111:1098-1119.

73. Pineiro G, Paruelo JM, Oesterheld M, Jobbágy EG. 2010. Pathways of grazing effects on soil organic carbon and nitrogen. Rangel Ecol Manag 63:109-119.

74. De Silva HN, Hall AJ, Tustin DS, Gandar PW. 1999. Analysis of distribution of root length density of apple trees on different dwarfing rootstocks. Ann Bot 83:335-345.

75. Schuman AGE, Reeder JD, Manley JT, Hart RH, Manley W a. 2013. Impact of Grazing Management on the Carbon and Nitrogen Balance of a Mixed-Grass Rangeland I. Ecol Appl 9:65-71.

76. Chaneton EJ, Lemcoff JH, Lavado RS. 1996. Nitrogen and phosphorus cycling in grazed and ungrazed plots in a temperate subhumid grassland in Argentina. J Appl Ecol 33:291.

77. Singh SK, Rai JPN. 2004. Soil microbial population and enzyme activity related to grazing pressure in alpine meadows of Nanda Devi Biosphere Reserve. J Environ Biol 25:103-107.

78. Bowles TM, Acosta-Martínez V, Calderón F, Jackson LE. 2014. Soil enzyme activities, microbial communities, and carbon and nitrogen availability in organic agroecosystems across an intensively-managed agricultural landscape. Soil Biol Biochem 68:252-262.

79. Bardgett RD, Wardle DA, Yeates GW. 1998. Linking above-ground and below-ground interactions: How plant responses to foliar herbivory influence soil organisms. Soil Biol Biochem 30:1867-1878.

80. Oesterheld M. 1992. Effect of defoliation intensity on aboveground and belowground realtive growth rates. Oecologia 92:313-316.

81. McCree KJ, Troughton JH. 1966. Non-existence of an optimum leaf area index for the production rate of white clover grown under constant conditions. Plant Physiol 41:16151622.

82. Butterbach-bahl K, Baggs EM, Dannenmann M, Kiese R. 2013. Nitrous oxide emissions from soils : how well do we understand the processes and their controls? Philos Trans R Soc London B Biol Sci 368.

83. Mosier AR. 1998. Soil processes and global change. Biol Fertil Soils 27:221-229.

84. Edwards JH, Thurlow DL, Eason JT. 1988. Influence of tillage and crop rotation on yields of corn, soybean, and wheat. Agron J 80:76.

85. Mosier A, Kroeze C, Nevison C, Oenema O, Seitzinger S. 1998. Closing the global $\mathrm{N} 2 \mathrm{O}$ budget : nitrous oxide emissions through the agricultural nitrogen cycle inventory methodology. Nutr Cycl Agroecosystems 52:225-248.

86. Dandie CE, Burton DL, Zebarth BJ, Henderson SL, Trevors JT, Goyer C. 2008. Changes in bacterial denitrifier community abundance over time in an agricultural field and their relationship with denitrification activity. Appl Environ Microbiol 74:5997-6005. 
87. Šimek M, Brůček P, Hynšt J, Uhlířová E, Petersen SO. 2006. Effects of excretal returns and soil compaction on nitrous oxide emissions from a cattle overwintering area. Agric Ecosyst Environ 112:186-191.

88. Thomas SM, Beare MH, Francis GS, Barlow HE, Hedderley DI. 2008. Effects of tillage, simulated cattle grazing and soil moisture on $\mathrm{N} 2 \mathrm{O}$ emissions from a winter forage crop. Plant Soil 309:131-145.

89. Davies MG, Smith KA, Vinten AJA. 2001. The mineralisation and fate of nitrogen following ploughing of grass and grass-clover swards. Biol Fertil Soils 33:423-434.

90. Mangalassery S, Sjögersten S, Sparkes DL, Sturrock CJ, Craigon J, Mooney SJ. 2014. To what extent can zero tillage lead to a reduction in greenhouse gas emissions from temperate soils? Sci Rep 4:4586.

91. Christopher SF, Lal R, Mishra U. 2009. Regional study of no-till effects on carbon sequestration in the midwestern United States. Soil Sci Soc Am J 73:207.

92. Firestone MK, Davidson EA. 1989. Microbiologial Basis of NO and N2O production and consumption in soil. Exch Trace Gases between Terr Ecosyst Atmos 7-21.

93. Tortoso AC, Hutchinson GL. 1990. Contributions of autotrophic and heterotrophic nitrifiers to soil $\mathrm{NO}$ and $\mathrm{N} 2 \mathrm{O}$ emissions contributions of autotrophic and heterotrophic nitrifiers soil no and N2O emissions. Appl Environ Microbiol 56:1799-1805.

94. Le J, Baujard E, Andreux F, Mathieu O, He C. 2006. Quantifying the contribution of nitrification and denitrification to the nitrous oxide flux using $15 \mathrm{~N}$ tracers. Soil Biol Biochem 144.

95. Wallenstein MD, Myrold DD, Firestone M, Voytek M. 2014. Environmental controls on denitrifying communities and denitrification rates : insights from molecular methods. Ecol Appl 16:2143-2152.

96. Robertson GP. 1989. Nitrification and denitrification in humid tropical ecosystems: potential controls on nitrogen retention. Miner Nutr Trop For savanna Ecosyst 55-69.

97. Yates CJ, Norton DA, Hobbs RJ. 2000. Grazing effects on plant cover, soil and microclimate in fragmented woodlands in south-western Australia: Implications for restoration. Austral Ecol 25:36-47.

98. Schimel J, Balser TC, Wallenstein M. 2015. Microbial stress-response physiology and Its implications for ecosystem function. Ecology 88:1386-1394.

99. Whitman WB, Coleman DC, Wiebe WJ. 1998. Prokaryotes: The unseen majority. Proc Natl Acad Sci 95:6578-6583.

100. Cuhel J, Simek M, Laughlin RJ, Bru D, Cheneby D, Watson CJ, Philippot L. 2010. Insights into the effect of soil $\mathrm{pH}$ on $\mathrm{N} 2 \mathrm{O}$ and $\mathrm{N} 2$ emissions and denitrifier community size and activity. Appl Environ Microbiol 76:1870-1878.

101. Henry S, Baudoin E, López-Gutiérrez JC, Martin-Laurent F, Brauman A, Philippot L. 2004. Quantification of denitrifying bacteria in soils by nirK gene targeted real-time 
PCR. J Microbiol Methods 59:327-335.

102. Lugato E, Lip A, Jones A. 2018. Mitigation potential of soil carbon management overestimated by neglecting N2O emissions. Nat Clim Chang 8:219-223.

103. Chambers A, Lal R, Paustian K. 2016. Soil carbon sequestration potential of US croplands and grasslands: Implementing the 4 per Thousand Initiative. J Soil Water Conserv 71:68A-74A.

104. Lugato E, Leip A, Jones A. 2018. Mitigation potential of soil carbon management overestimated by neglecting N2O emissions. Nat Clim Chang 8:219-223.

105. Pastorelli R, Landi S, Trabelsi D, Piccolo R, Mengoni A, Bazzicalupo M, Pagliai M. 2011. Effects of soil management on structure and activity of denitrifying bacterial communities. Appl Soil Ecol 49:46-58.

106. Chroňáková A, Radl V, Čuhel J, Šimek M, Elhottová D, Engel M, Schloter M. 2009. Overwintering management on upland pasture causes shifts in an abundance of denitrifying microbial communities, their activity and N2O-reducing ability. Soil Biol Biochem 41:1132-1138.

107. Krause HM, Thonar C, Eschenbach W, Well R, Mäder P, Behrens S, Kappler A, Gattinger A. 2017. Long term farming systems affect soils potential for N2O production and reduction processes under denitrifying conditions. Soil Biol Biochem 114:31-41.

108. Philippot L, Andert J, Jones CM, Bru D, Hallin S. 2011. Importance of denitrifiers lacking the genes encoding the nitrous oxide reductase for $\mathrm{N} 2 \mathrm{O}$ emissions from soil. Glob Chang Biol 17:1497-1504.

109. Braker G, Zhou J, Wu L, Devol AH, Tiedje JM. 2000. Nitrite reductase genes (nirK and nirS) as functional markers to investigate diversity of denitrifying bacteria in pacific northwest marine sediment communities. Appl Environ Microbiol 66:2096-2104.

110. Henry S, Bru D, Stres B, Hallet S, Philippot L. 2006. Quantitative detection of the nosZ gene, encoding nitrous oxide reductase, and comparison of the abundances of 16S rRNA, narG, nirK, and nosZ genes in soils. Appl Environ Microbiol 72:5181-5189.

111. Rocca JD, Hall EK, Lennon JT, Evans SE, Waldrop MP, Cotner JB, Nemergut DR, Graham EB, Wallenstein MD. 2015. Relationships between protein-encoding gene abundance and corresponding process are commonly assumed yet rarely observed. ISME J 9:1693-1699.

112. Chen Y, Wen Y, Zhou Q, Vymazal J. 2014. Effects of plant biomass on denitrifying genes in subsurface-flow constructed wetlands. Bioresour Technol 157:341-345.

113. Saarenheimo J, Rissanen AJ, Arvola L, Nykänen H, Lehmann MF, Tiirola M. 2015. Genetic and environmental controls on nitrous oxide accumulation in lakes. PLoS One 10:e0121201.

114. Fisher T. 2011. DNA and RNA molecular weights and conversions.

115. 2018. StatPlus: Mac. 6. AnalystSoft Inc. 
116. Fierer N, Schimel JP, Holden PA. 2003. Variations in microbial community composition through two soil depth profiles. Soil Biol Biochem 35:167-176.

117. Wallenstein MD, Weintraub MN. 2008. Emerging tools for measuring and modeling the in situ activity of soil extracellular enzymes. Soil Biol Biochem 40:2098-2106.

118. Holland JN, Cheng W, Crossley DA. 1996. Herbivore-induced changes in plant carbon allocation : assessment of below-ground C fluxes using carbon-14. Oecologia 107:87-94.

119. Evans PS. 1973. The effect of repeated defoliation to three different levels on root growth of five pasture species. New Zeal J Agric Res 16:31-34.

120. Richards JH. 1984. Root growth response to defoliation field observations with an improved root periscope. Oceologica 64:21-25.

121. Abalos D, De Deyn GB, Kuyper TW, van Groenigen JW. 2014. Plant species identity surpasses species richness as a key driver of $\mathrm{N} 2 \mathrm{O}$ emissions from grassland. Glob Chang Biol 20:265-275.

122. Di HJ, Cameron KC. 2002. Grassland. Soil Use Manag 18:395-403.

123. Bateman EJ, Baggs EM. 2005. Contributions of nitrification and denitrification to N2O emissions from soils at different water-filled pore space. Biol Fertil Soils 41:379-388.

124. Butterbach-Bahl K, Baggs EM, Dannenmann M, Kiese R, Zechmeister-Boltenstern S. 2013. Nitrous oxide emissions from soils: how well do we understand the processes and their controls? Philos Trans R Soc Lond B Biol Sci 368:20130122.

125. Mao Y, Yannarell AC, Mackie RI. 2011. Changes in N-Transforming archaea and bacteria in soil during the establishment of bioenergy crops. PLoS One 6:e24750.

126. Taghizadeh-Toosi A, Clough TJ, Condron LM, Sherlock RR, Anderson CR, Craigie RA. 2011. Biochar incorporation into pasture soil suppresses in situ nitrous oxide emissions from ruminant urine patches. J Environ Qual 40:468.

127. Fuller RJ, Norton LR, Feber RE, Johnson PJ, Chamberlain DE, Joys AC, Mathews F, Stuart RC, Townsend MC, Manley WJ, Wolfe MS, Macdonald DW, Firbank LG. 2005. Benefits of organic farming to biodiversity vary among taxa. Biol Lett 1:431-434.

128. Flessa H, Dörsch P, Beese F, König H, Bouwman AF. 1996. Influence of cattle wastes on nitrous oxide and methane fluxes in pasture land. J Environ Qual 25:1366.

129. Li W, Huang H-Z, Zhang Z-N, Wu G-L. 2011. Effects of grazing on the soil properties and $\mathrm{C}$ and $\mathrm{N}$ storage in relation to biomass allocation in an alpine meadow. J Soil Sci Plant Nutr 11:27-39.

130. Christensen S. 1983. Nitrous oxide emission from a soil under permanent grass: Seasonal and diurnal fluctuations as influenced by manuring and fertilization. Soil Biol Biochem 15:531-536.

131. Corre MD, van Kessel C, Pennock DJ. 1996. Landscape and seasonal patterns of nitrous oxide emissions in a semiarid region. Soil Sci Soc Am J 60:1806. 
